\title{
Listas dos quintos e do Real Donativo: atividades econômicas, mineração e escravidão no Termo de Vila Rica $(1715-31)^{\star}$
}

\author{
Mining Tax Lists: economic activities, mining and slavery in \\ Vila Rica, Minas Gerais (1715-31)
}

\author{
Tarcísio de Souza Gaspar $\star \star$
}

\begin{abstract}
Resumo: por meio da análise das listas tributárias dos quintos e do Real Donativo, este artigo estudou a composição e as características das propriedades, das posses e das atividades econômicas desenvolvidas em Vila Rica, um dos principais núcleos mineradores da América Portuguesa, no período entre 1715 e 1731. Além de apontar precauções e nuances metodológicas importantes no uso dessa documentação fiscal, o trabalho deteve-se na avaliação de caso de um contribuinte em específico: o capitão-mor Henrique Lopes de Araújo, minerador proprietário de rica lavra aurífera e indivíduo mais tributado nessas listas fiscais. Embora constate a inegável presença e o forte peso econômico de atividades agrícolas e comerciais - o que a historiografia especializada já destacou -, a pesquisa demonstrou que a mineração também constituiu setor econômico capaz de sustentar parte importante da classe senhorial, proprietária de extensos conjuntos de trabalhadores escravizados, e ainda outros grupos intermediários.
\end{abstract}

Palavras-chave: Listas fiscais. Mineração. Escravidão.

Abstract: Through the analysis of mining tax lists, this article studied the composition and characteristics of properties, possessions and economic activities developed in Vila Rica, one of the main mining centers in Portuguese America, in

\footnotetext{
* Submissão: 26/04/2020 | Aprovação: 27/06/2021 | DOI: 10.29182/hehe.v24i3.734

Este artigo valeu-se de dados e discussões parcialmente referenciados em minha tese de doutoramento, intitulada Tapanhuacanga em ruínas: história do Palácio Velho de Preto (c. 1660-1825), defendida em 2016 no Programa de Pós-Graduação em História Social da USP, sob orientação da professora Laura de Mello e Souza. Na realização dessa pesquisa, contei com apoios da Cátedra Jaime Cortesão e do Instituto Federal do Sul de Minas Gerais (IFSULDEMINAS). Agradeço, em especial, as contribuições e críticas que recebi dos professores Caio C. Boschi, Luciano Figueiredo e Guilherme Neves. Os erros, lapsos e omissões são de minha responsabilidade.

$\star \star$ Professor de História do Instituto Federal do Sul de Minas Gerais, Campus Muzambinho, Brasil | ORCID: 0000-0001-5811-9184 | E-mail: tarcisio.gaspar@gmail.com
} 
the period between 1715 and 1731. In addition to pointing out important precautions and methodological nuances in the use of this tax documentation, the work focused on evaluating the case of a specific taxpayer: main captain Henrique Lopes de Araújo, miner owner of a rich gold mine and the most taxed individual in these fiscal lists. Although noting the undeniable presence and the strong economic weight of agricultural and commercial activities - which specialized historiography has already highlighted -, the research showed that mining was also an economic sector capable of sustaining an important part of the landlord class, which owns extensive groups of workers enslaved, and still other intermediate groups.

Keywords: Tax lists. Mining. Slavery.

JEL: N56. N96. 


\section{Introdução}

Neste trabalho vamos analisar um conjunto documental específico, as listas tributárias dos quintos e do Real Donativo referentes ao Termo de Vila Rica entre 1715 e 1731. Para tanto, tomamos como referência o súdito pagante que maior contribuição deu aos cofres reais neste período e comparamos ostensivamente a sua situação às dos demais contribuintes deVila Rica. Henrique Lopes de Araújo foi, talvez, o mais bem-sucedido minerador da capitania de Minas Gerais na primeira metade do século XVIII. Sua propriedade aurífera, situada na encosta do morro de Tapanhuacanga, na freguesia de Antônio Dias, esteve entre as mais ricas e produtivas da capitania - afirmação que este trabalho tentou comprovar empiricamente - e chegou a empregar o maior conjunto de trabalhadores cativos da então capital mineira, em 1721. Ao contrastar a taxação fiscal imposta sobre essa propriedade àquela cobrada de outros empreendimentos econômicos de Vila Rica, é possível revelar informações importantes para o entendimento da realidade socioeconômica desta vila que detinha então o maior contingente escravizado e produzia a mais rica mineração de Minas Gerais naquele período.

Este artigo procurou identificar grupos socioeconômicos e hierarquias sociais explícitas nas faixas de propriedade ou fortuna e nas diferentes atividades produtivas que as listas fiscais discriminam. Neste caso, pudemos dimensionar o porte e a especificidade econômica de uma propriedade mineradora em particular. Situar no meio local a posição relativa do empreendimento de Henrique Lopes de Araújo permite explicar, em termos geográficos e econômicos, parte de seu significado e sua importância histórica. Escolhido por sede da recém-inaugurada capitania de Minas Gerais e por residência do governador dom Lourenço de Almeida a partir de 1721, o Palácio erguido por Henrique Lopes ao lado de sua própria residência e na vizinhança de suas terras minerais teve histórico singular. Com a morte de seu benfeitor, em 1733, e após perder a condição de sede política a partir de 1735, com a saída do Conde das Galvêas e a chegada de Gomes Freire de Andrada, as minas do Palácio Velho - como vieram a ser conhecidas - tornaram-se o núcleo de um mito afro-brasileiro e, ao que tudo indica, foram exploradas econômica e simbolicamente por uma poderosa comunidade de trabalhadores escravizados, organizada em torno da Irmandade dos negros do Alto da Cruz, em Vila Rica (Gaspar, 2016).

Também foi propósito deste artigo analisar uma rica região aurífera em momento no qual o ouro ainda era sabidamente abundante, a propiciar, por- 
tanto, uma rara oportunidade de observar as reais potencialidades, as interações e combinações da atividade mineradora junto aos demais empreendimentos econômicos nesse contexto. ${ }^{1}$ Com esse objetivo, travamos diálogo com diferentes fases e autores da historiografia econômica relacionada às Minas. Tendo claro que o espaço aurífero ensejou rica diversificação econômica - o que já foi sobejamente demonstrado na historiografia (Carrara, 2007; Lamas, 2008) -, a combinar atividades agrícolas, comerciais e de serviços, qual teria sido, neste contexto, a importância específica da mineração? Se o ouro de fato jamais pôde definir, por si, um ciclo, qual foi seu papel efetivo nessa miríade de relações produtivas e comerciais? Inscrito, já nos primeiros registros, entre as principais posses do Termo de Vila Rica, o complexo aurífero de Henrique Lopes instalava-se em espaço especialmente proficuo para a mineração. A freguesia de Antônio Dias foi, nas primeiras décadas do setecentos, a mais rica área aurífera de Minas Gerais e, no interior desse rincão privilegiado, a "praia de Henrique Lopes" ocupou posição central. A partir da análise dos dados expostos a seguir, essa e outras questões serão abordadas.

\section{Achegas à historiografia}

A crítica historiográfica que realçou a presença de atividades agrícolas, comerciais e artesanais no âmbito das Minas desempenhou papel fundamental no sentido de esclarecer a dinâmica real da economia e da sociedade colonial instalada sobre terrenos minerais e suas cercanias (Boschi, 1996; Boxer, 2000; Furtado, 2006). O complexo e multifacetado universo de relações econômicas que permitiu o nascimento, a sobrevivência e a reprodução de centenas de pequenos e médios núcleos populacionais - denominados arraiais, agregados ou não ao traçado de vilas (Damasceno, 2011) - e de milhares de empreendimentos agrícolas em seus campos, currais e sertões (Carrara, 2007) teve características absolutamente originais, quando comparado ao litoral açucareiro da América portuguesa. Permanecem válidos muitos dos pressupostos da tese formulada por Celso Furtado (2005) acerca das múltiplas “articulações” que a economia escravista mineira entabulara no século XVIII, a possibilitar o estabelecimento de relações econômicas entre diversas e muitas vezes distantes partes da América portuguesa, antes dispersas. Outros estudos também corrobo-

\footnotetext{
1 Como destacou Ângelo Carrara (2007), a maior disponibilidade de séries documentais produzidas no último terço do século XVIII e no primeiro quarto do século XIX dificultou o entendimento sobre a estrutura ocupacional das Minas no período anterior, quando a mineração atingiu seu ápice.
} 
raram a ideia de que, embora de menor rendimento geral comparativamente ao nordeste açucareiro, o mercado mineiro foi partilhado por contingente muito maior de atores econômicos, seja no que diz respeito à população livre, seja no afluxo de trabalhadores escravizados e forros (Furtado, 2006). Mas as discussões acerca dos mercados e fluxos internos, suas características e dinâmicas, bem como as considerações acerca da natureza geral da economia colonial nas Minas tornaram-se temas mais complexos, sobre os quais parece não haver consenso na atualidade. Mais recentemente, tem-se notado certo esforço por associar a economia mineira setecentista às configurações típicas do império português de Antigo Regime, em que redes sociais e comerciais transregionais e, muitas vezes, transatlânticas ligaram, por via mercantil, o "espaço econômico do ouro" a diferentes porções da América portuguesa e a outros domínios lusos na Europa, na África e na Ásia, a gerar dividendos apropriados em nível local por cada um dos agentes (Mathias, 2012).

Ora, ao analisar o complexo aurífero de Henrique Lopes em contraste com as demais propriedades de seu meio no Termo de Vila Rica, este artigo demonstrará que a atividade mineradora foi capaz, sim, de formar e engendrar no período e espaço estudados uma parte substancial do mercado local, a ponto de viabilizar a ocorrência de empreendimentos econômicos de relativo vulto que podiam, dada a sua rentabilidade excepcional, prescindir de combinações com propriedades de feição agrícola ou mercantil e, ainda, ostentar significativo número de capital mobilizado em trabalhadores escravizados, entre outros itens. Este foi precisamente o caso da propriedade aqui considerada.

\section{Listas fiscais}

Para o período entre 1715 e 1731, dispomos de oito listas tributárias que recaíram sobre a população do Termo deVila Rica parcial ou integralmente. Em todas, Henrique Lopes foi levado a rol. São elas as listas de pagamento dos quintos referentes aos anos de 1715,1718,1719, 1721 e 1722; e as planilhas do Real Donativo elaboradas entre 1729-31. Muito heterogêneas entre si, tais listas tiveram certas características em comum: identificavam, em entradas individuais, os nomes de moradores livres, economicamente ativos, situados em seus respectivos bairros ou arraiais de residência; e, de regra, apontavam o quantitativo (explícito ou estimado) das posses de cada pagante, mediante a descrição cuidadosa de suas propriedades escravistas, fundiárias e comerciais. 
Por outro lado, a metodologia de registro dos dados variou bastante de um rol para outro e mesmo no interior de uma mesma listagem (Faria, 2013). Distintos cobradores optaram por notações diferenciadas, desprovidas de padrão. Por isso é inadequado estabelecer cotejamento sistemático entre as cobranças, com base em variáveis fixas. Mas comparações específicas, atentas à diversidade documental, podem levantar informações úteis. Por exemplo, no que diz respeito à análise de propriedades escravistas, os dados permitem propor faixas classificatórias, estimadas conforme a envergadura e a tipologia dos planteis, dentro de uma mesma listagem anual, e ainda compará-las evolutivamente, contrastando anos ou períodos entre si. Resgatadas e utilizadas nas últimas duas ou três décadas por diversos historiadores, as fontes tributárias de Minas Gerais constituem acervo ímpar e sem paralelo no quadro da América portuguesa.Além de potencialidades relacionadas à demografia histórica, preocupada, sobretudo, com o problema das populações escravizadas da capitania, exploram-se, entre outros, temas como a história da escravidão e do tráfico negreiro, vislumbram-se clivagens e identidades sociais de cativos e de forros; demarcam-se grupos socioeconômicos e hierarquias sociais explícitas nas faixas de propriedade ou fortuna e nas diferentes atividades produtivas que as listas discriminam. (Carrara, 2007; Libby, 2007; Botelho, 2002; Fonseca; Paiva, 2010; Mata, 2006; Costa, 2010). Destacam-se também estudos que se valeram dessas fontes para botar em causa o próprio sistema fiscal ou de arrecadação de direitos que marcou fortemente a presença da Coroa portuguesa nas Minas (Vasconcellos, 1901; Cardozo, 1940; Faria, 2010, 2013, 2015; Costa, 2013). Nesse trabalho, tais fontes ajudaram a estabelecer a condição e a especificidade econômica de uma propriedade mineradora em seu meio local - uso que jamais lhes foi dado.

\section{Primeira lista dos quintos: $\mathbf{1 7 1 5}$}

Nos quintos de 1715, contabilizaram-se 1.376 registros de pagamentos individuais no Termo de Vila Rica. Contudo, o número de pagantes foi virtualmente menor, porque o mesmo contribuinte podia ser levado a rol dupla ou triplamente, quando detentor de posses em diferentes localidades ou quando possuidor de mais de um empreendimento num só local. Nesses casos, pela ocorrência de nomes incompletos ou omitidos, nem sempre foi possível distinguir as situações em que se tratava de um único contribuinte com mais de uma entrada daquelas em que havia homônimos com alistamentos dife- 
rentes. Atente-se também que muitos contribuintes estavam incursos em sociedades, dividindo a exploração de propriedade com parentes, sócios ou camaradas, ao mesmo tempo que possuíam suas próprias posses individuais, não partilhadas. Por isso, optou-se por analisar a totalidade das entradas e dos pagamentos, sem divisar o número de pagantes individuais. Seja como for, quando possível, a identificação de contribuintes que pagaram mais de uma vez permitiu descobrir, porventura, a diversidade da atuação econômica e a variedade de posses de um agente.

Os quintos de Vila Rica válidos entre 10 de julho de 1715 e a mesma data do ano seguinte deviam completar o total de seis arrobas, vinte quatro libras e setenta e duas oitavas de ouro, montante que coube à respectiva vila e seu termo, conforme houvera sido decidido no rateio das trinta arrobas de ouro a serem pagas por todas as Minas de Ouro, em acordo efetuado em fevereiro de $1715 .^{2}$ Essa forma de cobrança só fora estabelecida após uma série de distúrbios ocasionados pela tentativa de implantação do método de recolhimento do quinto por bateias, desejado pela coroa, que prometia taxar em até doze oitavas de ouro cada escravo minerador. Ante a resistência local, deflagrada por motins em Sabará, em Caeté e em Raposos, o então governador dom Brás Baltasar viu-se forçado a recuar, retornando ao que havia sido anteriormente acordado, ou seja, ao método por quota fixa de três dezenas de arrobas. Em novembro, a câmara nomeou cobradores responsáveis por efetuar a cobrança nos bairros e localidades do Termo de Vila Rica. Os cobradores deviam declarar os nomes dos moradores, os "cabedais, negros, lavras e roças que tivessem" e, com base em tais informações, à medida das posses de cada contribuinte, realizar o lançamento. ${ }^{3}$

As listas discriminaram-se por freguesia, bairro ou localidade, em dezenove áreas distintas. Os núcleos com maior número de pagantes foram, curiosamente, duas localidades rurais, Cachoeira do Campo e São Bartolomeu, com 293 e 224 entradas respectivamente. Em seguida vieram os dois principais núcleos de Vila Rica, os arraiais de Antônio Dias e Pilar do Ouro Preto, com 164 e 136 pagantes, respectivamente. Completaram o lançamento áreas adjacentes a esses arraiais, como o Morro, Bom Sucesso, Padre Faria e Ouro Bueno, na freguesia de Antônio Dias, assim como outros arraiais e áreas rurais, como Ouro Podre, Ouro Branco, Congonhas, Itatiaia e Itaubira, conforme se observa na Tabela 1.

\footnotetext{
${ }^{2}$ APM, SC 06, fls. 44-44v.

${ }^{3}$ APM, CMOP 02, p. 320-322.
} 
Tabela 1 - Número de pagamentos, valor médio em oitavas de ouro por pagamento; número de mulheres, de homens e de forros (as); pagantes por arraial no Termo de Vila Rica, quintos de 1715

\begin{tabular}{|c|c|c|c|c|c|}
\hline Arraial/Distrito & $\begin{array}{l}\text { Número de } \\
\text { pagamentos }\end{array}$ & $\begin{array}{l}\text { Valor médio } \\
\text { em oitavas } \\
\text { de ouro/ } \\
\text { pagamento }\end{array}$ & Mulheres & Homens & $\begin{array}{l}\text { Forros } \\
\quad \text { (as) }\end{array}$ \\
\hline Antônio Dias & 164 & 14,59 & 7 & 157 & 6 \\
\hline Bom Sucesso & 13 & 21,92 & - & 13 & - \\
\hline $\begin{array}{l}\text { Cachoeira do } \\
\text { Campo }\end{array}$ & 293 & 13,20 & 6 & 287 & 8 \\
\hline Campinho & 13 & 27 & - & 13 & - \\
\hline $\begin{array}{l}\text { Capanema e } \\
\text { Caraça }\end{array}$ & 19 & 14,52 & - & 19 & - \\
\hline Capão do Forno & 19 & 14,42 & - & 19 & - \\
\hline Congonhas & 68 & 10,10 & - & 68 & - \\
\hline $\begin{array}{l}\text { Fazendo do Lana } \\
\text { Até Tripuí }\end{array}$ & 47 & 13,39 & - & 47 & - \\
\hline Itatiaia & 69 & 14,72 & 4 & 65 & 6 \\
\hline Itaubira & 44 & 14,59 & - & 44 & 1 \\
\hline Morro & 27 & 26,14 & 4 & 23 & 4 \\
\hline Ouro Branco & 51 & 12,52 & 1 & 50 & - \\
\hline Ouro Bueno & 59 & 15,55 & 4 & 55 & 8 \\
\hline Ouro Podre & 52 & 14,28 & - & 52 & 5 \\
\hline $\begin{array}{l}\text { Padre Faria e } \\
\text { Córrego }\end{array}$ & 47 & 18,42 & - & 47 & - \\
\hline $\begin{array}{l}\text { Pilar do Ouro } \\
\text { Preto }\end{array}$ & 136 & 14,72 & 8 & 128 & 11 \\
\hline Rio das Pedras & 23 & 9,1 & 8 & 15 & 4 \\
\hline $\begin{array}{l}\text { Rodeio de } \\
\text { Itatiaia }\end{array}$ & 9 & 16,55 & - & 9 & - \\
\hline São Bartolomeu & 224 & 15,63 & 8 & 216 & 8 \\
\hline TOTAL & 1376 & 14,65 & 50 & 1316 & 61 \\
\hline
\end{tabular}

Fonte: APM, CMOP 02.

Outro aspecto a se notar na tabela acima é a rara presença, entre os pa- 
gantes, de mulheres e de ex-escravos (forros e forras). Homens livres foram a quase totalidade dos contribuintes, da ordem de $96,3 \%$. Somados, ex-cativas e ex-cativos alforriados representaram apenas $4,4 \%$ dos pagantes, a evidenciar que, nesse momento, a incidência de forros ainda era pequena. $O$ valor médio por pagamento atingiu 14,65 oitavas de ouro, correspondente a $21 \$ 975$ réis.

Além de cabedais, negros, lavras e roças, também foram considerados a propriedade de vendas, lojas, boticas, ranchos, sítios, engenhos, olarias, jiraus, cortes de gado (carne), posses em geral (especialmente em ouro) e aluguéis; e ainda a prática de ofícios mecânicos, o trato com gado ou simplesmente o envolvimento em negócio inespecífico. Na medida em que possuísse um ou mais desses bens e/ou exercesse quaisquer oficios, o contribuinte era tributado em razão diretamente proporcional ao lucro ou interesse capaz de extrair de tais posses e atividades. Raramente os cobradores especificaram a quantidade exata de um bem possuído pelo pagador. Quanto aos escravos, por exemplo, comum foi referir-se genericamente às posses do senhor, empregando o termo negro ou escravo no singular - quando se tratava de um único cativo ou no plural, para informar que havia maior número. Adotou-se o mesmo procedimento em relação aos bens imóveis, como roças (rocinhas, sítios e ranchos), vendas e lavras. No caso destas últimas, a indistinção entre singular e plural sequer tornou possível determinar se o registro se referia a apenas uma exploração mineral - o que forçou a consideração de critério genérico, a posse de lavras, desprovido de quantificação.

Numa entrada referente a um só pagador ou a uma sociedade que envolvesse dois ou mais indivíduos, podiam ser arrolados diversos bens e ofícios - e isso foi regra -, obrigando-se o(s) respectivo(s) contribuinte(s) a quitar o direito devido em função do conjunto de suas atividades e propriedades. Teoricamente, quão maiores e mais lucrativos fossem os empreendimentos de cada pagador, maior seria o valor a quitar. Mesmo considerando-se a ocorrência de desvios, adulterações e omissões resultantes da prática de sonegação dos quintos, a listagem de 1715, mais antiga do tipo em Vila Rica, constitui acervo documental de importância ímpar. ${ }^{4}$ Por meio dele, pode-se vislumbrar boa parcela da população livre economicamente ativa atuante no Termo de

\footnotetext{
${ }^{4} \mathrm{Na}$ Coleção da Casa dos Contos, em documentos sob a guarda do Arquivo Público Mineiro, existem registros mais antigos de pagamento dos quintos, mas concernentes a outras localidades de Minas Gerais. Para o Termo deVila Rica, no livro CC 1010, também no APM, há dados gerais e incompletos da cobrança efetuada em 1714. Além disso, o grosso desse volume corresponde à arrecadação relativa ao termo de Sabará. Nesse sentido, o acervo de 1715, completo e com a discriminação das entradas individuais dos pagantes, é o mais antigo referente a Vila Rica.
} 
Vila Rica.A estimativa de pagamento proporcional às posses e à lucratividade permite inferir, por comparação, grupos socioeconômicos discriminados conforme faixas de riqueza e áreas de atuação econômica. Além disso, a rudimentar especificação (e virtual quantificação) das propriedades alude aos tipos de empreendimento desenvolvidos, assim como aos padrões de atividade econômica de indivíduos e de grupos socioeconômicos. ${ }^{5}$

Outra utilidade é possibilitar a diferenciação entre as localidades formadoras do Termo de Vila Rica, seja divisando o número e as características de seus pagantes, seja atentando para a especialização das atividades desenvolvidas em nível local. Nota-se, por exemplo, a concentração de empreendimentos agrícolas em áreas marcadamente rurais, sobretudo Cachoeira do Campo e São Bartolomeu, ao passo que em núcleos mais densamente povoados houve a proliferação de vendas e lojas, rarefeitas em arraiais de menor porte.Também se concentraram nesses arraiais densamente povoados os oficiais mecânicos e os senhores portadores de um único escravo. $\mathrm{O}$ arraial de Antônio Dias apresentou a maior incidência de pagamentos por casa comercial, por oficio e por propriedade de escravo isolado. Detinha uma olaria, para atendimento à demanda de construções urbanas, a exemplo dos arraiais de Pilar do Ouro Preto e São Bartolomeu. Possuía ainda, a superar o Pilar e o Ouro Podre, o maior conjunto de cortes de carne e açougues, destinados a prover a alimentação do mais numeroso mercado consumidor deVila Rica. Os dados disponíveis transformam o arraial de Antônio Dias no núcleo populacional mais densamente povoado e no que detinha a mais notável feição urbana do Termo deVila Rica àquela altura, conforme demonstrado nas Tabelas 2 e 3.

\section{Tabela 2 - Pagamentos por roça, sítio, rancho, engenho, corte e trato de gado em Vila Rica (1715)}

\begin{tabular}{l|c|c|c|c|c|c|c}
\hline Arraial/Distrito & $\begin{array}{c}\text { Pagamentos } \\
\text { por roça }\end{array}$ & Rocinha & Sítio & Rancho & Engenho & Corte & $\begin{array}{c}\text { Trato } \\
\text { de } \\
\text { gado }\end{array}$ \\
\hline Antônio Dias & 1 & - & - & 2 & - & 4 & - \\
\hline Bom Sucesso & - & - & - & - & - & - & - \\
\hline $\begin{array}{l}\text { Cachoeira do } \\
\text { Campo }\end{array}$ & 126 & 8 & 5 & - & 1 & 1 & 1 \\
\hline
\end{tabular}

\footnotetext{
${ }^{5}$ Em 1955, Salomão de Vasconcelos, interessado em enumerar os primeiros habitantes de Ouro Preto, publicou um apanhado parcial dos pagamentos de 1715, limitando-se à transcrição dos registros referentes às freguesias de Antônio Dias e Pilar. Contudo, além de incompleta, a transcrição possui diversos equívocos e omissões, sobretudo na indicação das posses e atividades dos pagadores (Vasconcelos, 1955).
} 
Tabela 2 - Pagamentos por roça, sítio, rancho, engenho, corte e trato de gado em Vila Rica (1715)

\begin{tabular}{|c|c|c|c|c|c|c|c|}
\hline Arraial/Distrito & $\begin{array}{l}\text { Pagamentos } \\
\text { por roça }\end{array}$ & Rocinha & Sítio & Rancho & Engenho & Corte & $\begin{array}{c}\text { Trato } \\
\text { de } \\
\text { gado }\end{array}$ \\
\hline Campinho & - & - & - & - & - & - & - \\
\hline Capanema e Caraça & 1 & - & - & - & - & - & - \\
\hline Capão do Forno & 15 & 2 & - & - & - & - & - \\
\hline Congonhas & 23 & 3 & - & - & 1 & - & - \\
\hline $\begin{array}{l}\text { Fazendo do Lana } \\
\text { Até Tripuí }\end{array}$ & 33 & - & - & - & - & - & - \\
\hline Itatiaia & 17 & - & 1 & - & - & 1 & - \\
\hline Itaubira & 2 & - & - & - & 1 & - & 1 \\
\hline Morro & - & - & - & - & - & - & - \\
\hline Ouro Branco & 20 & 3 & 1 & - & 2 & - & 1 \\
\hline Ouro Bueno & - & - & - & - & - & - & 3 \\
\hline Ouro Podre & - & - & - & - & - & 2 & - \\
\hline $\begin{array}{l}\text { Padre Faria e } \\
\text { Córrego }\end{array}$ & 2 & - & - & - & - & - & - \\
\hline Pilar do Ouro Preto & - & - & - & - & 1 & 3 & 1 \\
\hline Rio das Pedras & - & - & - & - & - & - & 1 \\
\hline Rodeio de Itatiaia & 3 & 1 & 3 & - & - & - & - \\
\hline São Bartolomeu & 79 & 18 & 6 & - & 3 & - & - \\
\hline TOTAL & 322 & 35 & 16 & 2 & 9 & 11 & 8 \\
\hline
\end{tabular}

Fonte: APM, CMOP 02.

Tabela 3 - Pagamentos por escravo(s), loja, venda, ofício e olaria em Vila Rica (1715)

\begin{tabular}{l|c|c|c|c|c|c}
\hline Arraial/Distrito & $\begin{array}{c}\text { Pagamentos } \\
\text { por escravo } \\
\text { único }\end{array}$ & $\begin{array}{c}\text { Por mais } \\
\text { de um } \\
\text { escravo }\end{array}$ & $\begin{array}{c}\text { Por } \\
\text { loja }\end{array}$ & $\begin{array}{c}\text { Por } \\
\text { venda }\end{array}$ & $\begin{array}{c}\text { Por } \\
\text { ofício }\end{array}$ & $\begin{array}{c}\text { Por } \\
\text { olaria }\end{array}$ \\
\hline Antônio Dias & 21 & 71 & 29 & 34 & 38 & 1 \\
\hline Bom Sucesso & - & 3 & - & 1 & - & - \\
\hline $\begin{array}{l}\text { Cachoeira do } \\
\text { Campo }\end{array}$ & 5 & 146 & 2 & 7 & 13 & - \\
\hline Campinho & - & 8 & - & - & - & - \\
\hline
\end{tabular}


Tabela 3 - Pagamentos por escravo(s), loja, venda, ofício e olaria em Vila Rica (1715)

\begin{tabular}{|c|c|c|c|c|c|c|}
\hline Arraial/Distrito & $\begin{array}{l}\text { Pagamentos } \\
\text { por escravo } \\
\text { único }\end{array}$ & $\begin{array}{l}\text { Por mais } \\
\text { de um } \\
\text { escravo }\end{array}$ & $\begin{array}{l}\text { Por } \\
\text { loja }\end{array}$ & $\begin{array}{c}\text { Por } \\
\text { venda }\end{array}$ & $\begin{array}{l}\text { Por } \\
\text { ofício }\end{array}$ & $\begin{array}{l}\text { Por } \\
\text { olaria }\end{array}$ \\
\hline Capanema e Caraça & - & 11 & - & - & - & - \\
\hline Capão do Forno & - & 13 & - & - & - & - \\
\hline Congonhas & 4 & 42 & 1 & 1 & 4 & - \\
\hline $\begin{array}{l}\text { Fazendo do Lana Até } \\
\text { Tripuí }\end{array}$ & 1 & 28 & - & 2 & - & - \\
\hline Itatiaia & 7 & 40 & - & 1 & 5 & - \\
\hline Itaubira & - & 28 & - & 1 & - & - \\
\hline Morro & 1 & 16 & - & - & 4 & - \\
\hline Ouro Branco & 6 & 24 & - & 3 & 1 & - \\
\hline Ouro Bueno & 4 & 28 & 1 & 20 & 10 & - \\
\hline Ouro Podre & - & 31 & - & 26 & 7 & - \\
\hline $\begin{array}{l}\text { Padre Faria e } \\
\text { Córrego }\end{array}$ & - & 27 & - & 3 & - & - \\
\hline Pilar do Ouro Preto & 2 & 52 & 33 & 15 & 32 & 1 \\
\hline Rio das Pedras & - & 5 & - & 10 & 3 & - \\
\hline Rodeio de Itatiaia & - & 7 & - & - & - & - \\
\hline São Bartolomeu & 6 & 107 & - & 4 & 5 & 1 \\
\hline TOTAL & 57 & 687 & 66 & 128 & 122 & 3 \\
\hline
\end{tabular}

Fonte: APM, CMOP 02.

Demarcando-se faixas por dezenas de oitavas, verifica-se que 48,96\% dos débitos anotados (612 entradas) não ultrapassaram dez oitavas de ouro; outros 30,08\% (376 entradas) ficaram entre onze e vinte oitavas; 9,28\% (116 entradas) pagaram entre vinte e uma e trinta oitavas. Note-se, portanto, que quase noventa por cento $(88,32 \%)$ dos débitos atingiram, no máximo, três dezenas de oitavas. Por decorrência, as demais faixas obtiveram, respectivamente, percentagens irrisórias, sempre inferiores a cinco por cento dos pagadores. Somados, os contribuintes onerados em valor a partir de quarenta oitavas corresponderam a $8,24 \%$ dos registros (103 entradas). A seletividade aumenta entre aqueles responsáveis por montante a partir de cem oitavas, $0,8 \%$, isto é, apenas 10 entradas, num universo de 1.250 registros, conforme demonstra o Gráfico 1. 


\section{Gráfico 1 - Número e pagamentos por valor em oitavas de ouro no Termo de Vila Rica, quintos de 1715}

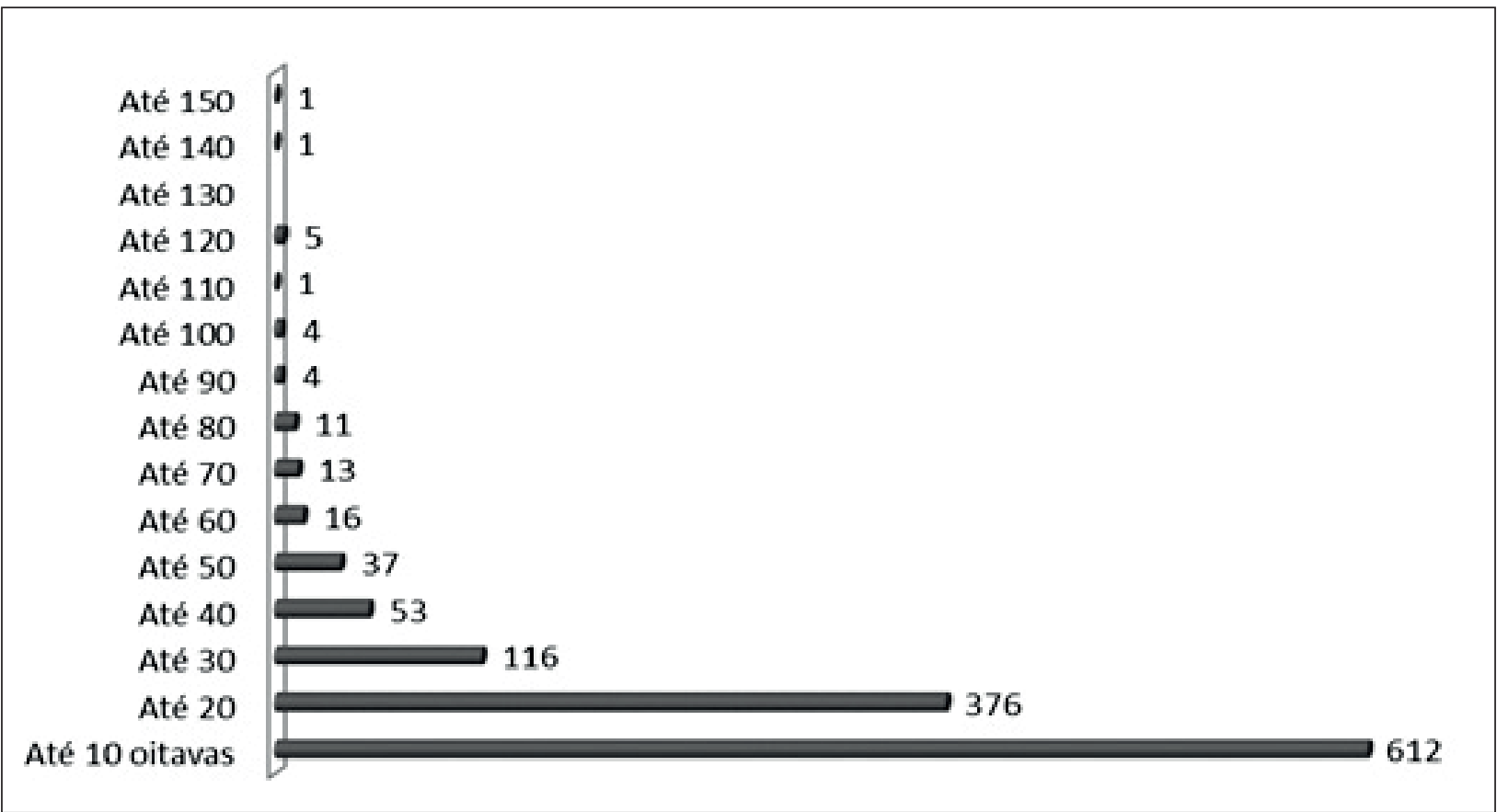

Fonte: APM, CMOP 02

Se Henrique Lopes achou-se entre os maiores contribuintes dos quintos, isso se deveu, em tese, ao fato de que a avaliação de seu patrimônio e a estimativa de lucratividade de seus empreendimentos alçavam-no à condição de um dos mais abastados habitantes do Termo deVila Rica em 1715. O capitão-mor pagou 138 oitavas "pelas suas lavras e negros". ${ }^{6}$ O registro de sua entrada não fez menção à posse de qualquer tipo de estabelecimento comercial. Trata-se, portanto, do primeiro indicativo de que Henrique Lopes houvesse abandonado o oficio de taberneiro e a propriedade de um corte de carne, trato comercial por ele mantido desde o período em que viveu no Rio de Janeiro até a chegada ao primitivo arraial de Antônio Dias.

Retomando dados constantes nas Tabelas 2 e 3 e comparando-os aos da Tabela 4, logo a seguir, é possível constatar que a incidência de débitos sobre propriedade escravista foi, de longe, o item mais recorrente. Débitos referentes a escravo isolado e a escravarias ocorreram 744 vezes, superando os registros de propriedades agrícolas e de estabelecimentos comerciais, com 375 e 205 aparições, respectivamente. Comprova-se com isso que a posse de mão de obra escrava era o tipo de propriedade mais amplamente disseminado

\footnotetext{
${ }^{6}$ APM, CMOP 02, p. 335.
} 
na sociedade local, constituindo, sem dúvida, o seu principal bem material ou investimento econômico, componente fundamental do sistema produtivo (Mathias, 2012). Por outro lado, a listagem de lavras demonstrou-se notoriamente subestimada. Em todo o lançamento, anotaram-se apenas trinta ocorrências de débito por posse de lavras; treze registros referiram-se a contribuintes mineiros; e outros dois, a faiscadores.

\section{Tabela 4 - Pagamentos por lavra, faiscação, ouro que tem e número de mineiros por arraial no Termo de Vila Rica, quintos de 1715}

\begin{tabular}{l|c|c|c|c}
\hline \multicolumn{1}{c|}{ Arraial/Distrito } & $\begin{array}{c}\text { Pagamento } \\
\text { por lavras }\end{array}$ & $\begin{array}{c}\text { Por } \\
\text { faiscação }\end{array}$ & $\begin{array}{c}\text { Por ouro } \\
\text { que tem }\end{array}$ & $\begin{array}{c}\text { Pagantes } \\
\text { mineiros }\end{array}$ \\
\hline 1. Antônio Dias & 1 & - & 3 & - \\
\hline 2. Bom Sucesso & 1 & - & - & - \\
\hline 3. Cachoeira do Campo & 1 & - & - & - \\
\hline 4. Campinho & - & - & - & 4 \\
\hline 5. Capanema e Caraça & 2 & - & - & - \\
\hline 6. Capão do Forno & - & - & - & - \\
\hline 7. Congonhas & 1 & - & - & - \\
\hline 8. Fazendo do Lana até Tripuí & 1 & - & - & - \\
\hline 9. Itatiaia & 7 & - & & - \\
\hline 10. Itaubira & 1 & - & & - \\
\hline 11. Morro & 1 & - & 1 & - \\
\hline 12. Ouro Branco & 4 & - & & - \\
\hline 13. Ouro Bueno & - & - & - & - \\
\hline 14. Ouro Podre & - & - & - & - \\
\hline 15. Padre Faria e Córrego & - & - & - & - \\
\hline 16. Pilar do Ouro Preto & 3 & 2 & - & - \\
\hline 17. Rio das Pedras & - & - & - & - \\
\hline 18. Rodeio de Itatiaia & - & - & - & - \\
\hline 19. São Bartolomeu & - & - & $\mathbf{2}$ & - \\
\hline TOTAL & - & - & - & - \\
\hline Fon:APM, CMOP & - & - & - & - \\
\hline
\end{tabular}

Fonte:APM, CMOP 02. 
É dificil medir o grau de omissão ou de imprecisão da lista. Avaliando o caso específico de Henrique Lopes, sabemos que chegou a possuir uma loja de fazenda no Rio de Janeiro, um corte de carne, já no arraial de Antônio Dias e, talvez no mesmo local, uma taverna. Nem uma palavra se disse acerca de sua atividade usurária, que sabemos ter exercido em vulto no último lustro de sua vida (Gaspar, 2016). Também não houve menção à posse de propriedade agrícola, senão mais tardiamente, na década de 1720 , quando o anfitrião de dom Lourenço de Almeida adquiriu uma roça no arraial de Bom Sucesso, a fim de fornecer frutas e madeiras ao palácio governamental. ${ }^{7}$ Apenas "lavras e negros" foram considerados no lançamento de 1715. Caso o capitão-mor tivesse, de fato, deixado àquela altura o trato comercial - que jamais lhe foi imputado em listas tributárias futuras -, a única omissão evidente seria a de seus aportes como usurário, prática que, inequivocamente,já exercia em 1715.

Suas práticas usurárias poderiam ter sido identificadas, como se deu, por exemplo, no registro do capitão Manoel Martins Carneiro, tributado em 57 oitavas "por si, [por] dois negros e [pelo] ouro que tem e se lhe deve". Causa reparo o contraste entre o pequeno número de escravos possuídos pelo pagador e o valor robusto da taxa, induzindo à impressão de que sua contribuição tenha sido calculada com base em sua atividade creditícia. O caso mais escandaloso de incidência fiscal sobre a usura ocorreu com o sargento-mor Arcangelo da Silva Vieira, onerado no caríssimo valor de 91 oitavas de ouro, "por si, [por] oito escravos que possui e [pelo] ouro que tem". ${ }^{9}$ Note-se que outros dois contribuintes, além dos já citados, foram tributados em função do ouro que possuíam, tomados, assim, tacitamente por credores. Curiosamente, três deles residiam no arraial e outro no morro de Antônio Dias, todos situados, portanto, no epicentro minerador deVila Rica (verTabela 4). Outros registros potenciais também se manifestaram de maneira velada. Dentre os maiores pagamentos, existiram dez menções a contribuintes onerados pelo que possuíam e outras três indicações de débito por cabedal, classificações que poderiam incluir, implicitamente, o trato creditício. Como se vê, o lançamento dos quintos de forma alguma mapeou a totalidade dos credores. O registro explícito condizente a Martins Carneiro foi exceção a romper regra de silêncio e de anonimato tradicionalmente atrelada à prática usurária.

\footnotetext{
${ }^{7}$ Em 1729, Henrique Lopes ainda devia a Manuel Gonçalves Bocaina 850 mil réis correspondentes a essa transação (ANTT, Conde de Linhares, mç. 95/2, fl. 2v).

${ }^{8}$ APM, CMOP 02, p. 341.

${ }^{9}$ APM, CMOP 02, p. 347.
} 
De forma estranha, os débitos por lavras manifestaram-se pulverizados, em pequenos conjuntos, por diversos arraiais. Chama atenção que localidades sabidamente imersas em faina extrativa, como os arraiais de Antônio Dias, Morro, Ouro Bueno, Bom Sucesso, Padre Faria, Pilar do Ouro Preto e Ouro Podre, apresentassem referências irrisórias à mineração, como se vê na Tabela 4. Em Antônio Dias, por exemplo, as únicas lavras mencionadas em rol foram justamente as de Henrique Lopes. Em vista das evidências, não há outra hipótese a considerar senão a de que a atividade mineradora tenha sido computada tacitamente nos principais núcleos mineradores. A disseminação generalizada da lide extrativa nesses arraiais mineradores deVila Rica tornou desnecessário o anúncio de tal atividade, fazendo-o subentendido. Isso explicaria o paradoxo de que localidades rurais, onde a incidência de mineração era rarefeita, apresentassem mais lavras levadas a rol que áreas voltadas exclusivamente para a extração de ouro.

Porque o acusamento de lavras em arraiais mineradores só ocorreu em situações extraordinárias, designadamente nos casos em que a lucratividade ou o porte do empreendimento fazia-o reparável a ponto de não poder ser omitido. Foi o que ocorreu, por exemplo, com o débito atribuído a Pedro de Barros, no arraial do Pilar, taxado em 57 oitavas de ouro pelo lucro presumido de sua atividade:"vive de faiscar com seus escravos". ${ }^{10}$ Considerando exclusivamente os registros de contribuintes com débitos mais elevados - a partir de 40 oitavas -, existiram apenas três menções à exploração de lavras: nos róis de Henrique Lopes de Araújo, em Antônio Dias; do doutor Ernesto Humberto, no Morro, onerado em 93 oitavas "pelas suas lavras e negros"; e de André Pires, em Bom Sucesso, que pagou 75 oitavas pelo mesmo tipo de propriedade. Nos demais lançamentos de vulto, os itens levados a rol limitaram-se, em geral, à propriedade de escravos, eventualmente conjugados à posse de roça, loja ou outros tipos de patrimônio. Citem-se, por exemplo, os débitos do mestre de campo Pascoal da Silva Guimarães, onerado em 90 oitavas de ouro "pelo que lucra com seus negros", no Morro de Antônio Dias; e do capitão Antônio Ramos dos Reis, no mesmo arraial, que arcou com 73 oitavas, também por seus escravos; e ainda o do capitão Antônio Martins Leça, já mencionado, maior pagador numa única entrada de 144 oitavas por “seus negros”.Vários exemplos semelhantes poderiam ser arrolados aqui: dentre os 106 maiores lançamentos, em 23 entradas (21,6\%) os contribuintes pagaram exclusivamente por seus escravos, como se vê na Tabela 5.A omissão da atividade mineral nos

\footnotetext{
${ }^{10}$ APM, CMOP 02, p. 369.
} 
lançamentos de senhores reconhecidamente envolvidos em faina extrativa reforça a excepcionalidade dos casos em que esse manifesto se deu. Nesse contexto, tudo leva a crer que as lavras possuídas por Henrique Lopes em sua propriedade à encosta do Tapanhuacanga e à margem dos ribeiros de Antônio Dias tenham sido identificadas por conta de sua lucratividade fora do comum.

Dado relevante extraído da Tabela 5 consistiu no alistamento de onze estabelecimentos comerciais (loja ou venda), a comprovar que entre os indivíduos mais abastados do Termo de Vila Rica constavam comerciantes que podiam ter na casa comercial o núcleo de suas atividades econômicas. $\mathrm{O}$ maior pagamento do tipo adveio de João Veloso de Carvalho, no Pilar, no valor de uma centena de oitavas "pelo lucro que tem na sua loja e negros". João Alverez, no mesmo arraial, anotou noventa oitavas "pelo que lucra na sua loja e cabedal". Aliás, o arraial do Pilar deteve o maior cartel de comerciantes taxados e os mais caros débitos cobrados de casas comerciais. Ali, identificaram-se seis lojas, oneradas em taxas que variaram entre 48 e 100 oitavas. Tal fato indica que, embora o arraial de Antônio Dias ostentasse maior número de empreendimentos comerciais, especialmente de vendas, era no Pilar que se concentravam lojas de porte e lucratividade superiores, como as "lojas de fazenda" possuídas pelo alferes Jorge de Macedo e pelo capitão João Ferreira. ${ }^{11}$ Para Sylvio deVasconcelos, a proeminência comercial deVila Rica transformava-a no "grande empório" das Minas, "previsto em sua criação e já perfeitamente caracterizado na capitação de 1715" (Vasconcelos, 1956). ${ }^{12}$

Nos maiores pagamentos, a presença de roças, engenhos e tratos com gado foi mais intensa em arraiais adjacentes aos principais núcleos mineradores. Na Tabela 5, citaram-se 46 roças, 6 engenhos e 2 estabelecimentos pecuários, concentrados nas áreas rurais de São Bartolomeu, Cachoeira do Campo, Congonhas, Ouro Branco, Itatiaia e Itaubira. Em 106 lançamentos, ocorreram 26 débitos por conjugação de escravos e roça (24,5\%) e 10 por escravos, lavras e roça $(9,4 \%)$, além de outras combinações de menor expres-

\footnotetext{
${ }^{11}$ APM, CMOP 02, p. 3650-84.

${ }^{12} \mathrm{O}$ autor equivoca-se, contudo, ao afirmar que os maiores pagamentos dos quintos de 1715 foram anotados por comerciantes. Segundo Vasconcelos, “não só, neste ano [de 1715], é maior o número de negociantes (cerca de 150), como os maiores lançamentos, correspondendo aos maiores recursos, neles se concentram, com poucas exceções. Henrique Lopes responsabiliza-se por 138, Pascoal da Silva por 90 e o capitão Antônio Martins Lessa por 144 oitavas de ouro. Lojistas, porém, lançados em 80, 90, em todo o caso acima de 50 oitavas, são frequentes, ao passo que os demais lançamentos oscilam em torno de 20 oitavas. E o próprio Pascoal da Silva, um dos maiores senhores de lavras, mas, antes mascate português, não deixaria de valer-se do comércio para com ele acumular maiores lucros". Julgo que, em vista da documentação de 1715, não há fundamento para se considerar que as entradas de Henrique Lopes, Martins Lessa e Pascoal da Silva Guimarães tenham sido motivadas por trato mercantil.
} 
são. Atente-se para o fato de que o maior número de lançamentos de vulto incidiu nos arraiais de São Bartolomeu e Cachoeira do Campo, respectivamente com 24 e 21 débitos a partir de quarenta oitavas. Ao mesmo tempo, esses arraiais apresentaram menor valor médio por lançamento do que o verificado em arraiais de viés minerador, como Antônio Dias, Morro e Ouro Bueno. Comparando-se as quatro localidades com maior número de pagantes, o arraial de Antônio Dias foi o que apresentou menor incidência relativa de lançamentos acima de quarenta oitavas: ali, houve um débito de vulto a cada vinte e sete contribuintes; enquanto no Pilar e em Cachoeira do Campo essa relação foi de doze e treze pagantes, respectivamente. São Bartolomeu, por sua vez, deteve o maior índice relativo de grandes débitos, com apenas nove contribuintes para cada lançamento acima de quarenta oitavas. Todos esses fatores, combinados, levam à impressão de que nas principais áreas rurais existiram mais propriedades de grande porte. Porém, esses empreendimentos de vulto tiveram ali menor lucratividade estimada do que a dos principais estabelecimentos situados em núcleos mineradores. Isto é, em zonas mineradoras, a riqueza atingiu maior valor e concentrou-se mais nas mãos de poucos indivíduos, comparativamente às áreas agropastoris - dado que ajuda a problematizar a tese clássica de Sérgio Buarque de Holanda (2013) a respeito da maior acessibilidade econômica proporcionada pela mineração. ${ }^{13}$ Essa hipótese coaduna-se ainda aos dados revelados nas Tabelas 1,2 e 3, comprobatórios de que o número de estabelecimentos agrícolas (roças, rocinhas, sítios e ranchos), com 375 ocorrências, foi significativamente maior do que a incidência de lavras e faisqueiras, com apenas 32 registros - muito embora, como vimos, $\mathrm{o}$ alistamento de mineradores não tenha refletido a realidade.

\section{Tabela 5 - Relação dos maiores débitos (a partir de 40 oitavas de ouro) no Termo de Vila Rica, quintos de 1715}

\begin{tabular}{l|l|l|c|c|c|c|c|c|c|c|c|c|c|c}
\hline & \multicolumn{1}{|c|}{ Arraial } & \multicolumn{1}{|c|}{ Nome } & I & II & III & IV & V & VI & VII & VIII & IX & X & XI & XII \\
\hline 1 & $\begin{array}{l}\text { Antônio } \\
\text { Dias }\end{array}$ & $\begin{array}{l}\text { Francisco dos } \\
\text { Santos }\end{array}$ & X & & & & & & & & & & & 45 \\
\hline
\end{tabular}

\footnotetext{
${ }^{13}$ Essa comparação é válida apenas para os arraiais com maior número de pagantes: Cachoeira do Campo, São Bartolomeu, Antônio Dias e Pilar do Ouro Preto. Se considerássemos áreas rurais menos ocupadas, teríamos resultados diferentes. Por exemplo, da Fazenda do Lana ao Tripuí e no arraial de Itaubira existiram apenas dois registros acima de quarenta oitavas, um em cada localidade, enquanto o número de entradas atingiu 47 e 44 lançamentos, respectivamente. Em tais áreas, a concentração relativa de riquezas nas mãos de poucos indivíduos era significativamente maior do que nas zonas mineradoras.
} 
Tabela 5 - Relação dos maiores débitos (a partir de 40 oitavas de ouro) no Termo de Vila Rica, quintos de 1715

\begin{tabular}{|c|c|c|c|c|c|c|c|c|c|c|c|c|c|c|}
\hline & Arraial & Nome & $\mathbf{I}$ & II & III & IV & $\mathbf{V}$ & VI & VII & VIII & IX & $\mathbf{X}$ & $\mathbf{X I}$ & XII \\
\hline 2 & $\begin{array}{l}\text { Antônio } \\
\text { Dias }\end{array}$ & $\begin{array}{l}\text { Henrique Lopes de } \\
\text { Araújo }\end{array}$ & $\mathrm{X}$ & $\mathrm{X}$ & & & & & & & & & & 138 \\
\hline 3 & $\begin{array}{l}\text { Antônio } \\
\text { Dias }\end{array}$ & $\begin{array}{l}\text { Manoel Martins } \\
\text { Carneiro }\end{array}$ & $\mathrm{X}$ & & $\mathrm{X}$ & & & & & & & & & 57 \\
\hline 3 & $\begin{array}{l}\text { Antônio } \\
\text { Dias }\end{array}$ & Manoel Rebelo & $\mathrm{X}$ & & & $\mathrm{X}$ & & & & & & & & 57 \\
\hline 4 & $\begin{array}{l}\text { Antônio } \\
\text { Dias }\end{array}$ & Manuel Lopes & $\mathrm{X}$ & & & & & & & & & & & 88 \\
\hline 5 & $\begin{array}{l}\text { Antônio } \\
\text { Dias }\end{array}$ & $\begin{array}{l}\text { Manoel de Souza } \\
\text { Ferreira }\end{array}$ & $\mathrm{X}$ & & & $\mathrm{X}$ & & & & & & & & 72 \\
\hline 6 & $\begin{array}{l}\text { Bom } \\
\text { Sucesso }\end{array}$ & André Pires & $\mathrm{X}$ & $\mathrm{X}$ & & & & & & & & & & 75 \\
\hline 7 & $\begin{array}{l}\text { Bom } \\
\text { Sucesso }\end{array}$ & $\begin{array}{l}\text { Sebastião Carlos } \\
\text { Leitão }\end{array}$ & $\mathrm{X}$ & & & & & & & & & & & 45 \\
\hline 8 & $\begin{array}{l}\text { Bom } \\
\text { Sucesso }\end{array}$ & $\begin{array}{l}\text { João de Barros } \\
\text { Rego }\end{array}$ & & & & & & & & & & & $\mathrm{X}$ & 70 \\
\hline 9 & $\begin{array}{l}\text { Cach. } \\
\text { Campo }\end{array}$ & $\begin{array}{l}\text { Antônio Gonçalves } \\
\text { Romão }\end{array}$ & $\mathrm{X}$ & & & & & $\mathrm{X}$ & & & & $\mathrm{X}$ & & 45 \\
\hline 10 & $\begin{array}{l}\text { Cach. } \\
\text { Campo }\end{array}$ & Antônio Paes & & & & & & & & & & $\mathrm{X}$ & & 60 \\
\hline 11 & $\begin{array}{l}\text { Cach. } \\
\text { Campo }\end{array}$ & $\begin{array}{l}\text { Caetano Alverez de } \\
\text { Araújo }\end{array}$ & $\mathrm{X}$ & & & & & $\mathrm{X}$ & & & & & & 40 \\
\hline 12 & $\begin{array}{l}\text { Cach. } \\
\text { Campo }\end{array}$ & $\begin{array}{l}\text { Constantino de } \\
\text { Paiva Pereira }\end{array}$ & $\mathrm{X}$ & & & & & $\mathrm{X}$ & & & & & & 50 \\
\hline 13 & $\begin{array}{l}\text { Cach. } \\
\text { Campo }\end{array}$ & $\begin{array}{l}\text { Domingos Carvalho } \\
\text { da Cunha }\end{array}$ & $\mathrm{X}$ & & & & & $\mathrm{X}$ & & & & & & 44 \\
\hline 14 & $\begin{array}{l}\text { Cach. } \\
\text { Campo }\end{array}$ & Domingos Dantas & & & & & & & & & & $\mathrm{X}$ & & 66 \\
\hline 15 & $\begin{array}{l}\text { Cach. } \\
\text { Campo }\end{array}$ & $\begin{array}{l}\text { Domingos } \\
\text { Lourenço São Payo }\end{array}$ & $\mathrm{X}$ & & & & & $\mathrm{X}$ & & & & & & 50 \\
\hline 16 & $\begin{array}{l}\text { Cach. } \\
\text { Campo }\end{array}$ & Estevão Ferreira & $\mathrm{X}$ & & & & & $\mathrm{X}$ & & & & & & 50 \\
\hline 17 & $\begin{array}{l}\text { Cach. } \\
\text { Campo }\end{array}$ & $\begin{array}{l}\text { Francisco de } \\
\text { Meireles }\end{array}$ & & & & & & & & & & & $\mathrm{X}$ & 40 \\
\hline 18 & $\begin{array}{l}\text { Cach. } \\
\text { Campo }\end{array}$ & Gonçalo da Rocha & $\mathrm{X}$ & & & & & $\mathrm{X}$ & & & & & & 45 \\
\hline 19 & $\begin{array}{l}\text { Cach. } \\
\text { Campo }\end{array}$ & Jacinto Moreira & $\mathrm{X}$ & & & & & & $\mathrm{X}$ & & & & & 40 \\
\hline
\end{tabular}


Tabela 5 - Relação dos maiores débitos (a partir de 40 oitavas de ouro) no Termo de Vila Rica, quintos de 1715

\begin{tabular}{|c|c|c|c|c|c|c|c|c|c|c|c|c|c|c|}
\hline & Arraial & Nome & $\mathbf{I}$ & II & III & IV & $\mathbf{V}$ & VI & VII & VIII & IX & $\mathbf{X}$ & XI & XII \\
\hline 20 & $\begin{array}{l}\text { Cach. } \\
\text { Campo }\end{array}$ & $\begin{array}{l}\text { João Martins } \\
\text { Nogueira }\end{array}$ & $\mathrm{X}$ & & & & & $\mathrm{X}$ & & & & & & 50 \\
\hline 21 & $\begin{array}{l}\text { Cach. } \\
\text { Campo }\end{array}$ & José de Sande & & & & & & & & & & $\mathrm{X}$ & & 120 \\
\hline 22 & $\begin{array}{l}\text { Cach. } \\
\text { Campo }\end{array}$ & José Ribeiro & $\mathrm{X}$ & & & & & $\mathrm{X}$ & & & & & & 54 \\
\hline 23 & $\begin{array}{l}\text { Cach. } \\
\text { Campo }\end{array}$ & Manoel Cardoso & & & & & & & & & & $\mathrm{X}$ & & 100 \\
\hline 24 & $\begin{array}{l}\text { Cach. } \\
\text { Campo }\end{array}$ & $\begin{array}{l}\text { Manoel Coelho } \\
\text { Ferreira }\end{array}$ & $\mathrm{X}$ & & & & & $\mathrm{X}$ & & & & & & 40 \\
\hline 25 & $\begin{array}{l}\text { Cach. } \\
\text { Campo }\end{array}$ & Manoel da Hora & $\mathrm{X}$ & & & & & $\mathrm{X}$ & & & & & & 40 \\
\hline 26 & $\begin{array}{l}\text { Cach. } \\
\text { Campo }\end{array}$ & $\begin{array}{l}\text { Martinho } \\
\text { Gonçalves }\end{array}$ & $\mathrm{X}$ & & & $\mathrm{X}$ & & $\mathrm{X}$ & & & & & & 64 \\
\hline 27 & $\begin{array}{l}\text { Cach. } \\
\text { Campo }\end{array}$ & Raphael Nunes & & & & & & & & & & $\mathrm{X}$ & & 50 \\
\hline 29 & $\begin{array}{l}\text { Cach. } \\
\text { Campo }\end{array}$ & Simão Fernandes & & & & & & & & & & $\mathrm{X}$ & & 64 \\
\hline 31 & $\begin{array}{l}\text { Cach. } \\
\text { Campo }\end{array}$ & $\begin{array}{l}\text { Simão Pereira de } \\
\text { Brito }\end{array}$ & $\mathrm{X}$ & & & & & $\mathrm{X}$ & & & & & & 40 \\
\hline 32 & Campinho & Antônio de Moura & $\mathrm{X}$ & & & & & & & & & & & 57 \\
\hline 33 & Campinho & $\begin{array}{l}\text { João da Silva } \\
\text { Guimarães }\end{array}$ & $\mathrm{X}$ & & & & & & & & & & & 46 \\
\hline 34 & Campinho & $\begin{array}{l}\text { João Gonçalves } \\
\text { Baptista }\end{array}$ & $\mathrm{X}$ & & & & & & & & & & & 56 \\
\hline 35 & Campinho & $\begin{array}{l}\text { Manoel Gomes da } \\
\text { Silva/Bento da Silva } \\
\text { Gomes (irmão), } \\
\text { Manoel da Rocha } \\
\text { (mesma casa) e } \\
\text { Manoel Martins }\end{array}$ & $\mathrm{X}$ & & & & & & & & & & & 114 \\
\hline 36 & $\begin{array}{l}\text { Capão } \\
\text { Forno }\end{array}$ & $\begin{array}{l}\text { João Monteiro } \\
\text { Santiago }\end{array}$ & $\mathrm{X}$ & & & & & $\mathrm{X}$ & & & & & & 50 \\
\hline 37 & Congonhas & $\begin{array}{l}\text { Matheus Rodrigues } \\
\text { do Prado }\end{array}$ & $\mathrm{X}$ & & & & & $\mathrm{X}$ & $\mathrm{X}$ & & & & & 40 \\
\hline 38 & Congonhas & $\begin{array}{l}\text { Matheus Rodrigues } \\
\text { Goularte }\end{array}$ & $\mathrm{X}$ & & & & & $\mathrm{X}$ & & & & & & 80 \\
\hline
\end{tabular}


Tabela 5 - Relação dos maiores débitos (a partir de 40 oitavas de ouro) no Termo de Vila Rica, quintos de 1715

\begin{tabular}{|c|c|c|c|c|c|c|c|c|c|c|c|c|c|c|}
\hline & Arraial & Nome & $\mathbf{I}$ & II & III & IV & $\mathbf{V}$ & VI & VII & VIII & IX & $\mathbf{X}$ & $\mathbf{X I}$ & XII \\
\hline 39 & Congonhas & $\begin{array}{l}\text { Pedro da Silva } \\
\text { Teixeira, }\end{array}$ & $\mathrm{X}$ & $\mathrm{X}$ & & & & $\mathrm{X}$ & & & & & & 64 \\
\hline 40 & $\begin{array}{l}\text { Lana/ } \\
\text { Tripuí }\end{array}$ & $\begin{array}{l}\text { Domingos de } \\
\text { Araújo Dantas }\end{array}$ & $\mathrm{X}$ & & & $\mathrm{X}$ & & & & & & & & 71 \\
\hline 41 & Itatiaia & $\begin{array}{l}\text { Antônio de Souza } \\
\text { (Licenciado)/ } \\
\text { Francisco de Souza } \\
\text { (irmão) }\end{array}$ & $\mathrm{X}$ & $\mathrm{X}$ & & & & $\mathrm{X}$ & & & & & & 40 \\
\hline 43 & Itatiaia & Constantino João & $\mathrm{X}$ & $\mathrm{X}$ & & & & $\mathrm{X}$ & & & & & & 68 \\
\hline 44 & Itatiaia & José [Meireles] & $\mathrm{X}$ & & & & & $\mathrm{X}$ & & & & & & 45 \\
\hline 45 & Itatiaia & Martinho Fernandes & $\mathrm{X}$ & $\mathrm{X}$ & & & & $\mathrm{X}$ & & & & & & 57 \\
\hline 46 & Itatiaia & Miguel de Barbosa & $\mathrm{X}$ & $\mathrm{X}$ & & & & $\mathrm{X}$ & & & & & & 57 \\
\hline 47 & Itaubira & Silvestre Souto & $\mathrm{X}$ & & & & & $\mathrm{X}$ & & $\mathrm{X}$ & & & & 112 \\
\hline 48 & Morro & $\begin{array}{l}\text { Antônio Ramos dos } \\
\text { Reis }\end{array}$ & $\mathrm{X}$ & & & & & & & & & & & 73 \\
\hline 49 & Morro & $\begin{array}{l}\text { Arcangelo da Silva } \\
\text { Vieira }\end{array}$ & $\mathrm{X}$ & & $\mathrm{X}$ & & & & & & & & & 91 \\
\hline 50 & Morro & $\begin{array}{l}\text { Domingos } \\
\text { Francisco de } \\
\text { Oliveira }\end{array}$ & $\mathrm{X}$ & & & & & & & & & & & 46 \\
\hline 52 & Morro & $\begin{array}{l}\text { Doutor Ernesto } \\
\text { Humberto }\end{array}$ & $\mathrm{X}$ & $\mathrm{X}$ & & & & & & & & & & 93 \\
\hline 53 & Morro & $\begin{array}{l}\text { Manoel de Souza } \\
\text { Serqueira }\end{array}$ & $\mathrm{X}$ & & & & & & & & & & & 80 \\
\hline 54 & Morro & $\begin{array}{l}\text { Pascoal da Silva } \\
\text { Guimarães }\end{array}$ & $\mathrm{X}$ & & & & & & & & & & & 90 \\
\hline 55 & $\begin{array}{l}\text { Ouro } \\
\text { Branco }\end{array}$ & $\begin{array}{l}\text { Antônio Borges e } \\
\text { seu irmão }\end{array}$ & $\mathrm{X}$ & $\mathrm{X}$ & & & & & & & & & & 40 \\
\hline 56 & $\begin{array}{l}\text { Ouro } \\
\text { Branco }\end{array}$ & Domingos Corrêa & $\mathrm{X}$ & & & & & $\mathrm{X}$ & $\mathrm{X}$ & $\mathrm{X}$ & & & & 41 \\
\hline 57 & $\begin{array}{l}\text { Ouro } \\
\text { Branco }\end{array}$ & $\begin{array}{l}\text { Domingos Moreira } \\
\text { (Alferes) }\end{array}$ & $\mathrm{X}$ & & & & & $\mathrm{X}$ & & & & & & 45 \\
\hline
\end{tabular}


Tabela 5 - Relação dos maiores débitos (a partir de 40 oitavas de ouro) no Termo de Vila Rica, quintos de 1715

\begin{tabular}{|c|c|c|c|c|c|c|c|c|c|c|c|c|c|c|}
\hline & Arraial & Nome & $\mathbf{I}$ & II & III & IV & $\mathbf{V}$ & VI & VII & VIII & IX & $\mathbf{X}$ & $\mathbf{X I}$ & XII \\
\hline 58 & $\begin{array}{l}\text { Ouro } \\
\text { Branco }\end{array}$ & Francisco de Bessa & $\mathrm{X}$ & & & $\mathrm{X}$ & & $\mathrm{X}$ & & & & $\mathrm{X}$ & & 45 \\
\hline 59 & $\begin{array}{l}\text { Ouro } \\
\text { Branco }\end{array}$ & $\begin{array}{l}\text { Amaro Ribeiro } \\
\text { Serra }\end{array}$ & $\mathrm{X}$ & $\mathrm{X}$ & & & & $\mathrm{X}$ & & & & & & 57 \\
\hline 60 & $\begin{array}{l}\text { Ouro } \\
\text { Bueno }\end{array}$ & $\begin{array}{l}\text { Antônio Martins } \\
\text { Leça }\end{array}$ & $\mathrm{X}$ & & & & & & & & & & & 144 \\
\hline 61 & $\begin{array}{l}\text { Ouro } \\
\text { Bueno }\end{array}$ & $\begin{array}{l}\text { Bartolomeu da } \\
\text { Costa }\end{array}$ & $\mathrm{X}$ & & & & & & & & & & & 41 \\
\hline 62 & $\begin{array}{l}\text { Ouro } \\
\text { Bueno }\end{array}$ & $\begin{array}{l}\text { Francisco Peixoto } \\
\text { Pinto }\end{array}$ & $\mathrm{X}$ & & & & & & & & & & & 50 \\
\hline 63 & $\begin{array}{l}\text { Ouro } \\
\text { Bueno }\end{array}$ & $\begin{array}{l}\text { Gaspar de Godoi } \\
\text { Ribeiro }\end{array}$ & $\mathrm{X}$ & & & & & & & & & & & 57 \\
\hline 64 & Ouro Podre & $\begin{array}{l}\text { Antônio da Costa } \\
\text { Gouveia }\end{array}$ & $\mathrm{X}$ & & & & & & & & & & & 43 \\
\hline 65 & Ouro Podre & $\begin{array}{l}\text { Manoel de Mello e } \\
\text { Horta }\end{array}$ & $\mathrm{X}$ & & & & & & & & & & & 57 \\
\hline 66 & $\begin{array}{l}\text { P. Faria/ } \\
\text { Corr. }\end{array}$ & $\begin{array}{l}\text { Domingos da } \\
\text { Rocha }\end{array}$ & $\mathrm{X}$ & & & & & & & & & & & 52 \\
\hline 67 & $\begin{array}{l}\text { P. Faria/ } \\
\text { Corr. }\end{array}$ & $\begin{array}{l}\text { Domingos } \\
\text { Francisco }\end{array}$ & & & & & & & & & & $\mathrm{X}$ & & 50 \\
\hline 68 & $\begin{array}{l}\text { P. Faria/ } \\
\text { Corr. }\end{array}$ & $\begin{array}{l}\text { João da Silva e seu } \\
\text { irmão }\end{array}$ & $\mathrm{X}$ & & & & & & & & & & & 61 \\
\hline 69 & $\begin{array}{l}\text { P. Faria/ } \\
\text { Corr. }\end{array}$ & João Pires & $\mathrm{X}$ & & & & & & & & & & & 50 \\
\hline 70 & $\begin{array}{l}\text { P. Faria/ } \\
\text { Corr. }\end{array}$ & Rafael Vaz da Silva & $\mathrm{X}$ & & & & & & & & & & & 45 \\
\hline 71 & Ouro Preto & $\begin{array}{l}\text { Domingos de Abreu } \\
\text { Lisboa }\end{array}$ & $\mathrm{X}$ & & & & & & & & & & & 43 \\
\hline 72 & Ouro Preto & Domingos Carvalho & $\mathrm{X}$ & & & $\mathrm{X}$ & & & & & & & & 50 \\
\hline 73 & Ouro Preto & João Alverez & & & & $\mathrm{X}$ & & & & & $\mathrm{X}$ & & & 90 \\
\hline 74 & Ouro Preto & $\begin{array}{l}\text { João Ferreira } \\
\text { (Capitão) }\end{array}$ & $\mathrm{X}$ & & & $\mathrm{X}$ & & & & & & & & 80 \\
\hline 75 & Ouro Preto & $\begin{array}{l}\text { João Veloso de } \\
\text { Carvalho }\end{array}$ & $\mathrm{X}$ & & & $\mathrm{X}$ & & & & & & & & 100 \\
\hline 76 & Ouro Preto & $\begin{array}{l}\text { Jorge de Macedo } \\
\text { (Alferes) }\end{array}$ & $\mathrm{X}$ & & & $\mathrm{X}$ & & & & & & & & 78 \\
\hline
\end{tabular}


Tabela 5 - Relação dos maiores débitos (a partir de 40 oitavas de ouro) no Termo de Vila Rica, quintos de 1715

\begin{tabular}{|c|c|c|c|c|c|c|c|c|c|c|c|c|c|c|}
\hline & Arraial & Nome & I & II & III & IV & $\mathbf{V}$ & VI & VII & VIII & IX & $\mathbf{X}$ & $\mathbf{X I}$ & XII \\
\hline 77 & Ouro Preto & $\begin{array}{l}\text { Manoel dos Santos } \\
\text { Larez }\end{array}$ & & & & & & & & & & & $\mathrm{X}$ & 45 \\
\hline 78 & Ouro Preto & $\begin{array}{l}\text { Manoel Tavares } \\
\text { Pereira }\end{array}$ & $\mathrm{X}$ & & & & & & & & & & & 43 \\
\hline 79 & Ouro Preto & Mathias Barbosa & & & & & & & & & & & $\mathrm{X}$ & 70 \\
\hline 80 & Ouro Preto & Pedro Barros & $\mathrm{X}$ & $\mathrm{X}$ & & & & & & & & & & 57 \\
\hline 81 & Ouro Preto & $\begin{array}{l}\text { Ventura Rodrigues } \\
\text { Velho }\end{array}$ & $\mathrm{X}$ & & & $\mathrm{X}$ & & & & & & & & 48 \\
\hline 82 & $\begin{array}{l}\text { Rod. } \\
\text { Itatiaia }\end{array}$ & $\begin{array}{l}\text { Simão da Cunha e } \\
\text { João Correa }\end{array}$ & $\mathrm{X}$ & & & & & $\mathrm{X}$ & & & & & & 50 \\
\hline 83 & S. Bart.meu & $\begin{array}{l}\text { Antônio Antunes } \\
\text { Franquelha }\end{array}$ & $\mathrm{X}$ & & & & & $\mathrm{X}$ & & & & & & 46 \\
\hline 84 & S. Bart.meu & Antônio Barbalho & $\mathrm{X}$ & & & & & $\mathrm{X}$ & & & & & & 59 \\
\hline 85 & S. Bart.meu & $\begin{array}{l}\text { Antônio Dias } \\
\text { Ferreira }\end{array}$ & & & & & & & & & & $\mathrm{X}$ & & 75 \\
\hline 86 & S. Bart.meu & $\begin{array}{l}\text { Antônio Montijo } \\
\text { de Florim }\end{array}$ & $\mathrm{X}$ & & & & $\mathrm{X}$ & $\mathrm{X}$ & & & & & & 45 \\
\hline 87 & S. Bart.meu & $\begin{array}{l}\text { Antônio Ribeiro } \\
\text { Franco }\end{array}$ & $\mathrm{X}$ & & & & & $\mathrm{X}$ & & & & & & 46 \\
\hline 88 & S. Bart.meu & $\begin{array}{l}\text { Baltasar Fernandes } \\
\text { Sarzedas }\end{array}$ & $\mathrm{X}$ & & & & & $\mathrm{X}$ & & & & & & 68 \\
\hline 89 & S. Bart.meu & $\begin{array}{l}\text { Domingos da } \\
\text { Cunha }\end{array}$ & $\mathrm{X}$ & $\mathrm{X}$ & & & & $\mathrm{X}$ & & & & & & 44 \\
\hline 90 & S. Bart.meu & $\begin{array}{l}\text { Francisco Coelho } \\
\text { da Silva }\end{array}$ & $\mathrm{X}$ & & & & & $\mathrm{X}$ & $\mathrm{X}$ & & & & & 57 \\
\hline 91 & S. Bart.meu & Francisco Leme & $\mathrm{X}$ & & & & & $\mathrm{X}$ & & & & & & 59 \\
\hline 92 & S. Bart.meu & $\begin{array}{l}\text { Francisco } \\
\text { Rodrigues }\end{array}$ & & & & & & & & & & & $\mathrm{X}$ & 70 \\
\hline 93 & S. Bart.meu & Frutuoso Alverez & $\mathrm{X}$ & $\mathrm{X}$ & & & & & & & & & & 68 \\
\hline 94 & S. Bart.meu & $\begin{array}{l}\text { Gaspar da Silva } \\
\text { Borges }\end{array}$ & $\mathrm{X}$ & & & & & $\mathrm{X}$ & & & & & & 45 \\
\hline 95 & S. Bart.meu & $\begin{array}{l}\text { Joao Carvalho } \\
\text { Oliveira }\end{array}$ & $\mathrm{X}$ & & & & & $\mathrm{X}$ & & & & & & 70 \\
\hline
\end{tabular}


Tabela 5 - Relação dos maiores débitos (a partir de 40 oitavas de ouro) no Termo de Vila Rica, quintos de 1715

\begin{tabular}{|c|c|c|c|c|c|c|c|c|c|c|c|c|c|c|}
\hline & Arraial & Nome & $\mathbf{I}$ & II & III & IV & $\mathbf{V}$ & VI & VII & VIII & IX & $\mathbf{X}$ & $\mathbf{X I}$ & XII \\
\hline 96 & S. Bart.meu & João Pinto da Silva & $\mathrm{X}$ & $\mathrm{X}$ & & & & $\mathrm{X}$ & & & & & & 109 \\
\hline 97 & S. Bart.meu & Manoel Antunes & $\mathrm{X}$ & & & & & $\mathrm{X}$ & & & & & & 70 \\
\hline 98 & S. Bart.meu & Manoel de Mattos & $\mathrm{X}$ & & & & & $\mathrm{X}$ & & & & & & 114 \\
\hline 99 & S. Bart.meu & $\begin{array}{l}\text { Manoel de Souza } \\
\text { Santiago }\end{array}$ & $\mathrm{X}$ & & & & & $\mathrm{X}$ & & & & & & 40 \\
\hline 100 & S. Bart.meu & $\begin{array}{l}\text { Manoel Gonçalves } \\
\text { Loureiro }\end{array}$ & $\mathrm{X}$ & & & & & & & & $\mathrm{X}$ & & & 42 \\
\hline 101 & S. Bart.meu & $\begin{array}{l}\text { Manoel Paes de } \\
\text { Souza }\end{array}$ & $\mathrm{X}$ & & & & & $\mathrm{X}$ & $\mathrm{X}$ & & & & & 114 \\
\hline 102 & S. Bart.meu & $\begin{array}{l}\text { Manoel Pinto da } \\
\text { Silva }\end{array}$ & & & & & & & & & & & $\mathrm{X}$ & 45 \\
\hline 103 & S. Bart.meu & $\begin{array}{l}\text { Miguel da Costa } \\
\text { Negrão }\end{array}$ & $\mathrm{X}$ & & & & & & & & $\mathrm{X}$ & & & 80 \\
\hline 104 & S. Bart.meu & Pedro Gomes & $\mathrm{X}$ & & & & & $\mathrm{X}$ & $\mathrm{X}$ & & & & & 57 \\
\hline 105 & S. Bart.meu & Santos Martins & $\mathrm{X}$ & $\mathrm{X}$ & & & & $\mathrm{X}$ & & & & & & 77 \\
\hline \multirow[t]{2}{*}{106} & S. Bart.meu & $\begin{array}{l}\text { Thomé de Andrade } \\
\text { Freire }\end{array}$ & & & & & & & & & & & $\mathrm{X}$ & 85 \\
\hline & & TOTAIS & 86 & 15 & 2 & 11 & 1 & 46 & 6 & 2 & 3 & 10 & 7 & 6.442 \\
\hline
\end{tabular}

I -Escravos; II- Lavras/Faiscação; III- Ouro; IV - Loja/Venda;V- Olaria;VI - Roça/Sítio;VII - Engenho; VIII - Trato de Gado; IX - Cabedal; X - Pelo que possui; XI - Sem especificação; XII - Número de oitavas de ouro pagas.

Fonte: APM, CMOP 02.

Refinando a análise até os dez maiores lançamentos, conforme demonstrado a seguir, na Tabela 6 , observam-se sete registros oriundos de localidades predominantemente rurais (três em São Bartolomeu, dois em Cachoeira do Campo, um no Campinho e outro em Itaubira), e apenas três situados em zonas mineradoras - muito embora os dois maiores lançamentos, de Martins Leça e de Henrique Lopes, viessem dessas áreas. Senhores como o capitão Manoel de Mattos e Manoel Paes de Souza, em São Bartolomeu, e Silvestre Souto, em Itaubira, possuíam roças equipadas com escravaria, engenho e trato de gado respectivamente. A envergadura dos núcleos rurais, sobretudo dos arraiais de São Bartolomeu e Cachoeira do Campo, reforça a leitura de que, 
já em 1715, explorações agropastoris virtualmente voltadas para o abastecimento interno possuíssem condições econômicas comparáveis ou mesmo superiores à grande parte das lides minerárias.

\section{Tabela 6 - Relação dos dez maiores pagamentos do Termo de Vila Rica, quintos de 1715}

\begin{tabular}{c|l|l|c}
\hline & \multicolumn{1}{|c|}{ Nome } & \multicolumn{1}{|c}{ Arraial } & Valor \\
\hline 1 & Antônio Martins Leça (Capitão) & Ouro Bueno & 144 \\
\hline 2 & Henrique Lopes de Araújo (Capitão-mor) & Antônio Dias & 138 \\
\hline 3 & José de Sande & $\begin{array}{l}\text { Cachoeira do } \\
\text { Campo }\end{array}$ & 120 \\
\hline 4 & Manoel de Mattos (Capitão) & São Bartolomeu & 114 \\
\hline 5 & $\begin{array}{l}\text { Manoel Gomes da Silva/Bento da Silva Gomes } \\
\text { (irmão), Manoel da Rocha (mesma casa) e } \\
\text { Manoel Martins }\end{array}$ & Campinho & 114 \\
\hline 6 & $\begin{array}{l}\text { Manoel Paes de Souza e seu camarada Antônio } \\
\text { Correia }\end{array}$ & São Bartolomeu & 114 \\
\hline 7 & Silvestre Souto & Itaubira & 112 \\
\hline 8 & João Pinto da Silva (Capitão) & São Bartolomeu & 109 \\
\hline 9 & João Veloso de Carvalho & $\begin{array}{l}\text { Pilar do Ouro } \\
\text { Preto }\end{array}$ & 100 \\
\hline 10 & Manoel Cardoso & $\begin{array}{l}\text { Cachoeira do } \\
\text { Campo }\end{array}$ & 100 \\
\hline
\end{tabular}

Fonte: APM, CMOP 02.

Apesar de representarem apenas 8,24\% dos lançamentos, os débitos a partir de quarenta oitavas alavancaram quase 32\% (6.442 oitavas) do montante arrecadado em toda a listagem (20.163 oitavas), como exposto na Tabela 5. Isso não significa, contudo, que indivíduos enriquecidos tenham sido lesados em demasia.Ao contrário, no método por quota fixa, seguido em 1715, esses homens foram o grupo social mais beneficiado, arcando com quantia relativamente menor. Estima-se que se o método de cobrança por bateias tivesse sido instituído, nos moldes intentados pelo rei, o ônus material incidente sobre os maiores proprietários de escravos seria muito maior. ${ }^{14}$ Isso pode ser

\footnotetext{
${ }^{14}$ Em novembro de 1714, D. João V ordenou que a cobrança dos quintos incidisse exclusivamente sobre os escravos mineradores (ou seja, sobre as bateias), impondo-se a cada um deles doze oitavas de ouro. Por outro lado, as cargas de escravos, gados e utensílios deveriam sofrer cobrança moderada. Noutra carta, escrita em sequência e na mesma data da primeira, o rei relativizou a exigência, permitindo ao governador
} 
demonstrado para o caso de Henrique Lopes. Embora se ignore o quantitativo possuído pelo capitão-mor em 1715, sabe-se que, três anos depois, assenhoreava escravaria formada por 48 pessoas. ${ }^{15}$ Se tivesse tal propriedade num virtual lançamento por bateias, seu ônus não seria menor que 460 oitavas, podendo mesmo chegar a 552 oitavas de ouro na hipótese de que a imposição sobre cada escravo minerador chegasse a doze oitavas de ouro, como se defendera inicialmente. Ora, nessa circunstância, a rejeição do sistema por bateias e a consequente manutenção do método por quota fixa possibilitaram a Henrique Lopes uma economia mínima de 333\% no valor de sua contribuição. Vantagem semelhante, pode-se imaginar, foi usufruída por todos os senhores das Minas.

Resta ainda cotejar os contribuintes responsáveis por pagamento de duas ou mais entradas. Os casos mais importantes de registro duplo ou triplo em que foi possível excluir a homonímia e certificar a identidade do pagante revelaram a estratégia de diversificação econômica mantida por alguns dos homens principais de Vila Rica, que investiram em frentes diferentes, visando por vezes fatias distintas de mercado, a exemplo do que fizeram Antônio Martins Leça, Constantino de Paiva Pereira, Manoel Gomes da Silva, o mestre de campo Pascoal da Silva Guimarães e ainda Manoel Cardoso, entre outros. Martins Leça foi, por larga margem, o indivíduo que maior quantia despendeu nos quintos de 1715 no Termo de Vila Rica. Pagou triplamente: pela propriedade onde residia no arraial de Ouro Bueno, onerada na maior entrada isolada, como vimos; e ainda por duas roças no arraial de São Bartolomeu (uma delas possuída em sociedade com Manuel Coelho, também morador em Ouro Bueno), ambas equipadas com escravaria. Pelas roças e escravos nelas existentes desembolsou outras 39 oitavas, que, somadas ao primeiro registro, atingiram a cifra recorde de 183 oitavas de ouro, quase meia centena de oitavas a mais que o segundo maior pagador, que seguiu sendo Henrique Lopes, com 138 oitavas. Uma tipologia semelhante se deu nas entradas do mestre de campo Pascoal da Silva Guimarães que, além da posse minerária no Morro de Antônio Dias, também detinha roça e escravos no arraial de São Bartolomeu, pelos quais pagou mais 34 oitavas, acumulando, na totalidade, 124 oitavas. Uma mesma lógica econômica esteve presente nas posses de Martins Leça e de

conseguir ajuste em que a imposição sobre as bateias diminuísse de doze para dez oitavas (APM, SC 04, fls. 103-107).

${ }^{15}$ APM, CC 1028, fl. 57v. 
Silva Guimarães: a conjugação de explorações auríferas e agropastoris, simultaneamente.

Outros preferiram concentrar-se num único nicho econômico, como, por exemplo, Constantino de Paiva Pereira, senhor de três roças (duas em São Bartolomeu e uma em Cachoeira do Campo), dotadas de escravarias próprias, das quais resultou débito acumulado de 80 oitavas de ouro. Manoel Cardoso também se concentrou em atividades vinculadas ao abastecimento interno, ao possuir um engenho com escravos em Cachoeira do Campo e outra propriedade escravista (não especificada) em Itaubira, onerando-se cumulativamente em 136 oitavas - o terceiro maior débito individual. Por sua vez, Manoel Gomes da Silva, além do empreendimento em sociedade com o irmão e com outros dois sujeitos no distrito de Campinho, assenhoreou mais uma roça em S. Bartolomeu, também trabalhada por escravos. Ao recompilar a lista dos dez maiores pagamentos, incluindo-se contribuintes onerados em entradas duplas ou triplas, tem-se o resultado exposto na Tabela 7.

Tabela 7 - Relação dos dez maiores pagamentos do Termo de Vila Rica, quintos de 1715, considerando-se entradas duplas e triplas

\begin{tabular}{c|l|l|c}
\hline \multicolumn{2}{c|}{ Nome } & \multicolumn{1}{|c}{ Arraiais } & Valor \\
\hline 1 & Antônio Martins Leça (Capitão) & $\begin{array}{l}\text { Ouro Bueno e São } \\
\text { Bartolomeu }\end{array}$ & 183 \\
\hline 2 & Henrique Lopes de Araújo (Capitão-mor) & Antônio Dias & 138 \\
\hline 3 & Manoel Cardoso & $\begin{array}{l}\text { Cachoeira do Campo e } \\
\text { Itaubira }\end{array}$ & 136 \\
\hline 4 & Manoel Gomes da Silva e sócios & $\begin{array}{l}\text { Campinho e São } \\
\text { Bartolomeu }\end{array}$ & 130 \\
\hline 5 & $\begin{array}{l}\text { Pascoal da Silva Guimarães (Mestre de } \\
\text { Campo) }\end{array}$ & Morro e São Bartolomeu & 124 \\
\hline 6 & José de Sande & Cachoeira do Campo & 120 \\
\hline 7 & Manoel de Mattos (Capitão) & São Bartolomeu & 114 \\
\hline 8 & $\begin{array}{l}\text { Manoel Paes de Souza e seu camarada } \\
\text { Antônio Correia }\end{array}$ & São Bartolomeu & 114 \\
\hline 9 & Silvestre Souto & Itaubira & 112 \\
\hline 10 & João Pinto da Silva (Capitão) & São Bartolomeu & 109 \\
\hline
\end{tabular}

Fonte: APM, CMOP 02. 
Note-se que, entre os cinco indivíduos mais tributados de Vila Rica, apenas Henrique Lopes não possuía propriedade agrícola. E, entre os dez, apenas ele dedicava-se exclusivamente à mineração, sem outro tipo de atividade econômica declarada. Essas informações têm significado especial, por se referirem a um plebeu minhoto que exercera em Portugal, da infância até a idade madura, atividades ligadas ao manejo agropastoril (Gaspar, 2016). Em vista do que sabemos de suas posses e finanças, não há dúvida de que dispusesse de meios próprios à compra de uma ou mais propriedades rurais. Como de fato veio a fazer posteriormente, na década seguinte, ao adquirir uma roça em Bom Sucesso, usada para as necessidades do palácio. Mas, antes disso, o fato de não diversificar suas atividades econômicas para além da mineração faz pensar numa escolha explícita, amparada, decerto, na lucratividade obtida com a extração aurífera. Símbolo de poder e de distinção no Velho Mundo, base de sustentação da nobreza e do clero, e recurso imprescindível à classe dominante colonial situada no litoral açucareiro, o senhorio de terras também foi importante nas Minas, onde ganhou, todavia, um significado novo, mais próximo do utilitarismo, especialmente nas primeiras décadas do século XVIII. Nas Minas, e apenas nas Minas, tornara-se possível ascender ao grupo mais proeminente da sociedade local prescindindo-se da terra como fator de distinção e de reconhecimento social.

\section{Quintos de 1718 e 1719: róis de escravos}

As listas dos quintos dos anos de 1718 e 1719 referentes ao Termo de Vila Rica sobreviveram incompletas e subdivididas em diversos livros, agrupados na Coleção da Casa dos Contos, na seção sob a guarda do Arquivo Público Mineiro. Nessas listas, faltaram registros condizentes às Freguesias do Pilar do Ouro Preto, Cachoeira do Campo, Itaubira e Congonhas. Para a sede, restaram planilhas da freguesia de Antônio Dias, aparentemente incompletas, mas, por ventura, salvaram-se as entradas pagas por Henrique Lopes de Araújo. ${ }^{16}$ Apesar de muito mutilado, esse acervo é potencialmente mais rico e mais informativo que a documentação produzida em 1715, pois traz indicação precisa do número de escravos possuídos pelo senhor/pagante e também identifica os nomes e as procedências dos cativos, permitindo ainda distinguir gênero e, em alguns casos, idade (criança,jovem ou adulto) e condição social (solteiro,

\footnotetext{
${ }^{16}$ Para esses dois anos, referentes aos bairros e arraiais que compunham o Termo de Vila Rica, existem os seguintes livros: para a Freguesia de Antônio Dias, CC 1028 e CC 1039; para o arraial de São Sebastiao, CC 1024; para São Bartolomeu, CC 1025; para Itatiaia, CC 1030; e para Ouro Branco, CC 1037.
} 
casado) dos indivíduos levados a rol. O quantitativo de vendas e lojas, discriminado separadamente, também é imputado a seus respectivos proprietários, agrupados por bairro. Mas não houve individuação de ofícios mecânicos e tampouco especificaram-se os tipos de empreendimentos desenvolvidos pelo contribuinte. Se, por um lado, as lacunas impedem a comparação entre as diferentes áreas e arraiais do Termo de Vila Rica e omitem certos dados presentes em 1715, por outro, o detalhamento desse acervo oferece aquilo que a listagem anterior não deu a conhecer, isto é, o caráter e a composição das escravarias.

$\mathrm{Na}$ freguesia de Antônio Dias situavam-se sete arraiais ou distritos formadores. A área principal, mais povoada, com maior número de pagantes e detentora do maior contingente de escravos, era o arraial que emprestava nome à freguesia. Ali, 132 moradores, quase a metade (45\%) dos contribuintes residentes na freguesia, pagaram os quintos em 1718 e responderam por 632 escravos, corespondentes a 33,8\% da massa cativa arrolada, conforme demonstra a Tabela 8. Outro arraial muito povoado foi o de Padre Faria, com um quarto dos pagantes e pouco mais que isso relativamente aos escravos. Ora, comparadas às entradas registradas nos mesmos arraiais em 1715, que alcançaram 335 pagamentos (ver Tabela 1), as listas de 1718 apresentaram abatimento de quase cem contribuintes. É dificil saber se essa diminuição deveu-se ao desaparecimento de planilhas, à sonegação de nomes ou se, de fato, houve decréscimo da população fixada na freguesia de Antônio Dias entre um ano e outro.

Tabela 8 - Número de senhores e de escravos nos arraiais da freguesia de Antônio Dias, quintos de 1718

\begin{tabular}{l|r|r|r|r|r}
\hline \multicolumn{1}{c|}{ Arraiais } & Senhores & $\mathbf{\%}$ & Escravos & $\boldsymbol{\%}$ & $\begin{array}{c}\text { Média } \\
\text { Escravos/ Pagante }\end{array}$ \\
\hline Antônio Dias & 133 & 45 & 624 & 33,8 & 4,72 \\
\hline Bom Sucesso & 2 & 0,6 & 62 & 3,3 & 31 \\
\hline Córrego Seco & 44 & 14,9 & 333 & 18 & 7,5 \\
\hline Morro & 8 & 2,7 & 69 & 3,7 & 8,6 \\
\hline Ouro Bueno & 30 & 10,1 & 219 & 11,8 & 7,3 \\
\hline Ouro Podre & 6 & 2 & 27 & 1,4 & 4,4 \\
\hline Padre Faria & 72 & 24,4 & 507 & 27,5 & 7,1 \\
\hline TOTAL & $\mathbf{2 9 5}$ & $\mathbf{1 0 0}$ & $\mathbf{1 8 4 1}$ & $\mathbf{1 0 0}$ & $\mathbf{6 , 2}$ \\
\hline
\end{tabular}

Fonte: APM, CC 1028. 
A média de escravos por proprietário variou de um arraial para outro, mantendo-se a razão geral de 6,2 cativos por senhor. Na realidade, porém, a concentração de trabalhadores em poucas escravarias e a dispersão da posse escravista por miríade de pequenos proprietários deram a tônica do escravismo na freguesia de Antônio Dias. Conforme apontado no Gráfico 2, a grande maioria dos pagantes declarou posse diminuta, inferior à média. Cerca de $16 \%$ dos contribuintes tinham apenas um e outros $48 \%$ possuíam de dois a cinco escravos. Conjuntos acima de vinte cativos foram arrolados por somente doze proprietários, uma nata senhorial correspondente a $4 \%$ dos registros. Esses poucos grandes senhores detiveram 429 escravos, representativos de quase um quarto do total $(23,3 \%)$. Individualmente, o capitão-mor de Vila Rica arrolou a maior escravaria, superada, contudo, por duas propriedades exploradas em sociedade. Essa relação confirma a manutenção de Henrique Lopes como um dos principais senhores de Vila Rica (ver Tabela 9).

Por sua vez, o rol nominal de proprietários de vendas e de lojas situadas na freguesia tornou a confirmar que Henrique Lopes não se incluía entre os comerciantes locais. Chama atenção a profusão de vendas e de pequenos estabelecimentos comerciais concentrados no arraial de Antônio Dias, que também abrigou quase a totalidade das lojas, conforme se vê na Tabela 10. Inequivocamente, o arraial sede da freguesia ocupou posição de centralidade urbana ante os demais distritos formadores. Ao possuir algumas das principais lavras e congregar o maior contingente de senhores e de escravos tributados,Antônio Dias também dispôs do mais amplo leque de empreendimentos comerciais.

\section{Gráfico 2 - Número de senhores por número de escravos na Freguesia de Antônio Dias, quintos de 1718}

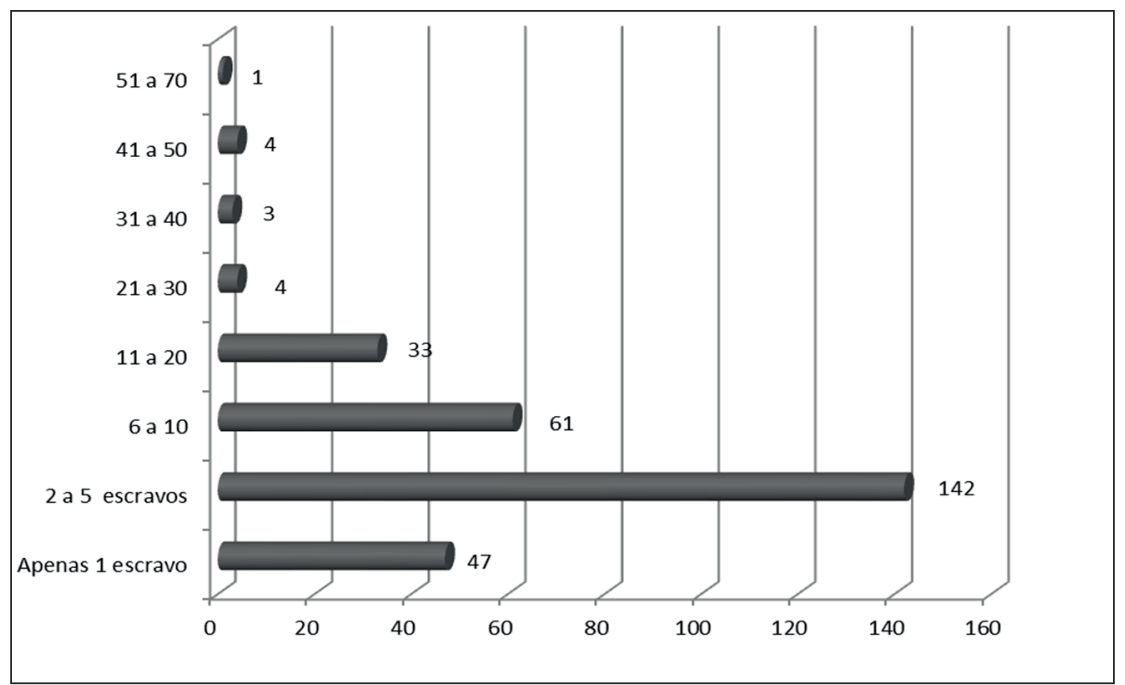

Fonte: APM, CC 1028. 
Tabela 9 - Relação dos principais senhoes de escravos da freguesia de Antônio Dias, quintos de 1718

\begin{tabular}{l|c|c}
\hline \multicolumn{1}{c|}{ Nome } & N. de escravos & \multicolumn{1}{c}{ Arraial } \\
\hline $\begin{array}{l}\text { 1. Sargento-mor Antônio Martins Leça e Manoel } \\
\text { Coelho Neto (sócios) }\end{array}$ & 62 & Ouro Bueno \\
\hline $\begin{array}{l}\text { 2. Capitão Manoel de Souza Sirqueira (sócio com } \\
\text { Custódio da Silva) }\end{array}$ & 48 & Córrego Seco \\
\hline 3. Capitão-mor Henrique Lopes de Araújo & 46 & Antônio Dias \\
\hline 4. Manoel Fernandes dos Reis & 43 & Bom Sucesso \\
\hline $\begin{array}{l}\text { 5. João dos Santos Braga (sócio com André Pires } \\
\text { da Costa) }\end{array}$ & 43 & Padre Faria \\
\hline 6. Manoel Gonçalves Porto & 34 & Antônio Dias \\
\hline 7. José da Silva pelo mestre de campo Pascoal da & 31 & Morro \\
Silva Guimarães & 31 & Córrego Seco \\
\hline 8. Luís Coelho dos Santos & 24 & Antônio Dias \\
\hline 9. Capitão Francisco da Costa de Oliveira & 23 & Córrego Seco \\
\hline 10. João Francisco Pimenta & 22 & Padre Faria \\
\hline 11. João Álvares Pereira & 22 & Padre Faria \\
\hline 12. Jorge Vieira & $\mathbf{4 2 9}$ & \\
\hline TOTAL & & \\
\hline Fonte:APM, CC 1028. & & \\
\hline
\end{tabular}

Fonte: APM, CC 1028.

\section{Tabela 10 - Vendas e lojas da freguesia de Antônio Dias, quintos de 1718}

\begin{tabular}{l|c|c|c}
\hline \multicolumn{1}{c|}{ Arraiais } & Vendas & Lojas & Total \\
\hline Antônio Dias & 58 & 13 & 71 \\
\hline Padre Faria & 21 & 1 & 22 \\
\hline Ouro Podre & 5 & 1 & 5 \\
\hline Ouro Bueno & & $\mathbf{1 5}$ & 1 \\
\hline \multicolumn{2}{l|}{ TOTAL } & $\mathbf{8 4}$ & $\mathbf{9 9}$ \\
\hline
\end{tabular}

Fonte: APM, CC 1028.

Os quintos de 1719 seguiram a mesma metodologia da cobrança antecedente, porém incidiram sobre maior número de senhores e de escravos. As divisões e subdivisões internas da freguesia de Antônio Dias também se 
alteraram. Arraiais como Ouro Podre, Ouro Bueno e Córrego Seco foram compreendidos no interior do bairro denominado genericamente "Morro", ao passo que o distrito de Bom Sucesso se incluiu no arraial de Padre Faria. Explica-se, assim, o inchaço repentino dos números correspondentes a esses dois bairros. A Tabela 11 expõe o quantitativo de 2.460 escravos distribuídos por 334 senhores, em média geral de 7,3 cativos por proprietário. Relativamente ao ano anterior, esses números representaram aumento de um terço no alistamento de senhores (39 contribuintes a mais) e acréscimo de 619 escravos declarados. Além disso, houve elevação da média geral de escravos por proprietário, que subiu de 6,2 para 7,3.

Tabela 11 - Número de senhores e de escravos por bairro da freguesia de Antônio Dias, quintos de 1719

\begin{tabular}{|l|c|c|c|c|c|}
\hline Arraiais/Bairros & Senhores & $\mathbf{\%}$ & Escravos & $\mathbf{\%}$ & $\begin{array}{c}\text { Média } \\
\text { Escravos/Senhor }\end{array}$ \\
\hline Antônio Dias & 131 & 39,2 & 639 & 25,9 & 4,8 \\
\hline Padre Faria & 89 & 26,6 & 779 & 31,6 & 8,7 \\
\hline Morro & 114 & 34,1 & 1042 & 42,3 & 9,1 \\
\hline TOTAL & $\mathbf{3 3 4}$ & $\mathbf{1 0 0}$ & $\mathbf{2 4 6 0}$ & $\mathbf{1 0 0}$ & $\mathbf{7 , 3}$ \\
\hline
\end{tabular}

Fonte: APM, CC 1028 e 1039.

\section{Gráfico 3 - Número de senhores por número de escravos na freguesia de Antônio Dias, quintos de 1719}

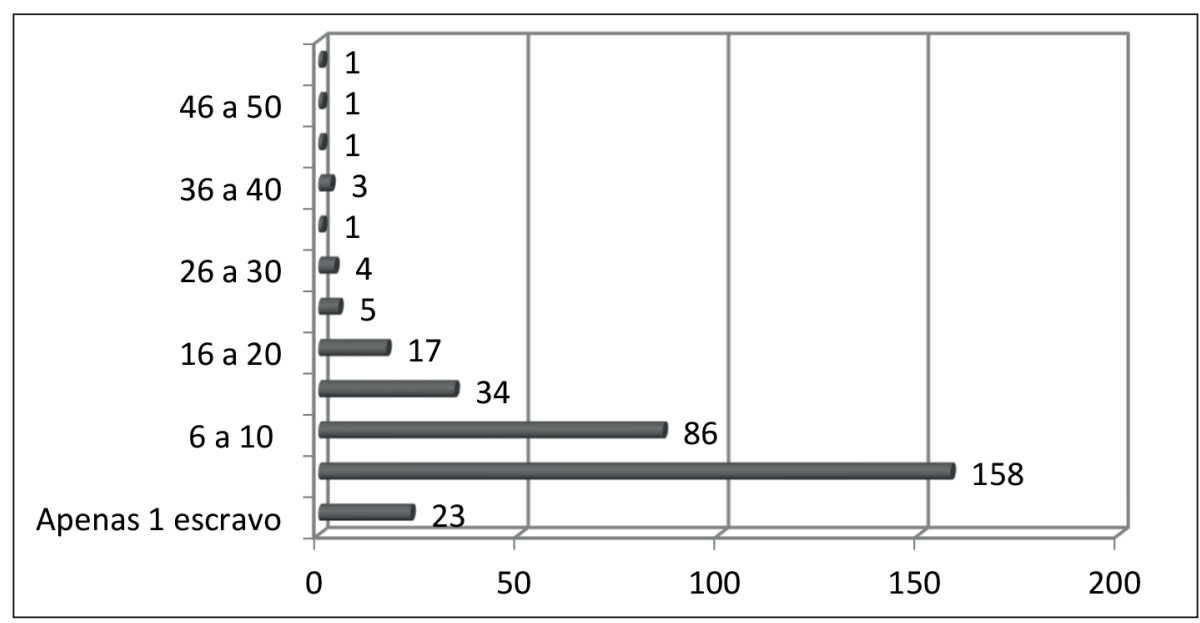

Fonte: APM, CC 1028 e 1039.

Já por meio do Gráfico 3 é possível visualizar esse crescimento através 
da composição das escravarias, observando-se o número de escravos arrolados por senhor. Indicaram a posse de apenas um cativo vinte e três proprietários (6,8\%), enquanto 158 senhores detiveram entre dois e cinco (47,3\%). Coletivos de seis a vinte escravos foram declarados por 137 senhores (ou 41\%). Somadas, essas faixas perfizeram quase a totalidade dos lançamentos, incluindo $95,1 \%$ dos contribuintes onerados. Uma minoria inferior a 5\% dos senhores, composta por dezesseis homens, concentrou as maiores escravarias.

Henrique Lopes declarou possuir a terceira maior propriedade escravista da freguesia de Antônio Dias em 1719. Foi superado novamente pelo sargento-mor Antônio Martins Leça e, uma novidade, por Pascoal e João da Silva Guimarães, pai e filho, que pagaram conjuntamente. Muito embora se saiba que Martins Leça mantivera, em 1715 e em 1718, sociedade com Manuel Coelho Neto, nesse lançamento sua entrada não indicou o estabelecimento de parceria. Por seu lado, foi a primeira vez que os Silva Guimarães se enquadraram numa única cobrança. Nos anos anteriores, suas propriedades haviam sido tomadas individualmente, o que decerto obrigara o clã familiar ao desprendimento de soma mais elevada. Em 1719, o mestre de campo Pascoal da Silva ocupou o cargo de juiz ordinário da câmara de Vila Rica, posição que teria lhe conferido meios de orientar a forma de cobrança, a fim de, quem sabe, diminuir o próprio ônus. Conforme mostra a Tabela 12, dentre os principais senhores, sete residiam no Morro, cinco em Padre Faria e apenas dois em Antônio Dias. Os escravos pertencentes a esses proprietários equivaleram a um quinto dos cativos dados a rol na freguesia.

\section{Tabela 12 - Principais senhores da freguesia de Antônio Dias, quintos de 1719}

\begin{tabular}{l|l|c}
\hline \multicolumn{1}{c|}{ Senhores } & Bairro/Arraial & Escravos \\
\hline 1. Sargento-mor Antônio Martins Leça & Morro & 62 \\
\hline $\begin{array}{l}\text { 2. João da Silva (pelo mestre de campo Pascoal da } \\
\text { Silva Guimarães) }\end{array}$ & Morro & 48 \\
\hline 3. Capitão-mor Henrique Lopes & Antônio Dias & 42 \\
\hline 4. André Pires da Costa & Padre Faria & 38 \\
\hline 5. Sargento-mor Manuel de Souza Siqueira & Morro & 38 \\
\hline $\begin{array}{l}\text { 6. Manoel Gonçalves Porto } \\
\text { 7. Luís Coelho dos Santos (sócio do cap. Francisco } \\
\text { Rodrigues Graça) }\end{array}$ & Morro & 36 \\
\hline
\end{tabular}


Tabela 12 - Principais senhores da freguesia de Antônio Dias, quintos de 1719

\begin{tabular}{l|l|c}
\hline \multicolumn{1}{c|}{ Senhores } & Bairro/Arraial & Escravos \\
\hline 8. João Francisco Pimenta & Morro & 30 \\
\hline 9. Antônio Dias & Padre Faria & 26 \\
\hline 10. Capitão Antônio Francisco de Miranda & Padre Faria & 26 \\
\hline 11. Jorge da Costa & Padre Faria & 23 \\
\hline 12. Antônio Ferreira Barreto (por Jorge de & Padre Faria & 21 \\
Lacerda) & Antônio Dias & 21 \\
\hline 13. Capitão Francisco da Costa de Oliveira & Morro & 21 \\
\hline 14. Domingos Ferreira & & $\mathbf{5 1 2}$ \\
\hline TOTAL & & \\
\hline
\end{tabular}

Fonte: APM, CC 1028 e 1039.

Escravaria composta por quarenta e duas pessoas foi a menor manifestada por Henrique Lopes nas listas de que dispomos e, como se verá, destoou das demais entradas nas quais suas posses foram computadas. Dois anos depois, sua propriedade escravista atingiu quase o dobro da lista declarada em 1719, o que faz pensar na possibilidade de que tenha sonegado suas posses nessa cobrança. Seja como for, mesmo omitindo parte de seu patrimônio senhorial, Henrique Lopes ainda despontava como principal proprietário de escravos e único grande minerador sediado no arraial de Antônio Dias.

\section{Quintos de 1721 e 1722: quantitativos de escravos anônimos}

Diferentemente do método seguido em 1715, em que o valor de pagamento individual foi calculado com base na estimativa das posses e dos lucros auferidos pelo contribuinte, e também de forma distinta ao que havia sido feito em 1718 e 1719, quando os róis indicaram o nome, o gênero e o grupo de procedência dos escravos, os quintos de 1721 e 1722 basearam-se no arrolamento sistemático do número de cativos por senhor, sem identificar individualmente os escravos. A propriedade escravista foi taxada em uma oitava, três quartos e quatro vinténs de ouro per capita e cada loja ou venda saiu a nove (em 1721) ou oito (em 1722) oitavas de ouro.A partir das listagens é possível obter quantitativos dessas categorias. Além da ressalva quanto à 
sonegação, comum a todas as fontes tributárias do período, deve-se observar ainda que o somatório de escravos não pode ser tomado ao pé da letra por outro motivo. Em alguns casos o arrolamento computou forros, forras e pessoas livres com poucas posses como se cativos fossem. Isso aconteceu, sobretudo, quando o senhor/contribuinte desempenhava atividade mecânica igual ou similar à que, virtualmente, seria exercida por seu(s) escravo(s). Cite-se, por exemplo, o rol de Eugênia, parda forra, moradora no arraial de Ouro Preto, que pagou por si e por um escravo, onerando-se em cota correspondente à propriedade de dois cativos. Iguais a esse existiram outros lançamentos. ${ }^{17}$ O procedimento parece ter sido regra válida em todos os casos em que o senhor exercesse atividade prática passível de tributação, mesmo tratando-se de pessoa livre. Como tal exercício não foi discriminado na documentação, torna-se inviável distinguir as entradas que consideraram apenas a propriedade escrava propriamente dita, daquelas em que o senhor também foi contabilizado entre a massa cativa.

Não obstante isso, as listas de 1721 e 1722 se preservaram razoavelmente completas. Dezesseis arraiais incluídos no Termo deVila Rica tiveram seus senhores e seus escravos quantificados. Para a pesquisa aqui desenvolvida, essa documentação foi particularmente relevante, pois permitiu situar a posição de Henrique Lopes junto a um amplo conjunto de proprietários de escravos, constituído por 1.761 senhores. Por outro lado, sua propriedade escravista também foi colocada em perspectiva com um extenso universo de trabalhadores cativos, formado por quase onze mil pessoas.

A Tabela 13 comprova que o arraial de Antônio Dias seguia sendo a área mais dinâmica de Vila Rica, ao concentrar o maior número de proprietários de escravos. Isoladamente, o arraial possuiu o segundo contingente de escravos, com quase mil trabalhadores cativos, superado apenas por São Bartolomeu, o principal distrito rural inserido no Termo de Vila Rica, e ainda ostentou o segundo conjunto de estabelecimentos comerciais. Entretanto, considerando-se que de modo contíguo ao arraial sede localizavam-se outros arraiais também bastante povoados, como Córrego Seco, Ouro Bueno, Ouro Fino, Ouro Podre e Padre Faria, a posição de centralidade da freguesia de Antônio Dias se torna mais evidente. Esses arraiais responderam por 34\% da classe senhorial (600 proprietários) e pelo mesmo percentual de trabalhadores escravizados (3.478 escravos). Já os distritos situados na parte baixa da freguesia

\footnotetext{
${ }^{17} \mathrm{Na}$ listagem de 1721, existem os casos de Antônio forra e Amaro Borges, em Ouro Preto. Em 1722, registra-se ainda o nome de Maria forra (APM, CMOP 11).
} 
(Antônio Dias e Padre Faria) abrigaram 119 pontos comerciais, quase a metade $(44,5 \%)$ dos empreendimentos congêneres no Termo de Vila Rica.

\section{Tabela 13 - Número de senhores de escravos e de vendas no Termo de Vila Rica, quintos de 1721}

\begin{tabular}{|c|c|c|c|c|c|c|}
\hline Arraial/Distrito & Senhores & $\%$ & Escravos & $\%$ & $\begin{array}{c}\text { Média } \\
\text { Escravos/ } \\
\text { Senhor }\end{array}$ & $\begin{array}{c}\text { Vendas } \\
\text { lojas }\end{array}$ \\
\hline 1. Antônio Dias & 220 & 12,4 & 995 & 9,0 & 4,5 & 62 \\
\hline 2. Bocaina & 86 & 4,8 & 390 & 3,5 & 4,5 & 9 \\
\hline $\begin{array}{l}\text { 3. Cachoeira do } \\
\text { Campo }\end{array}$ & 192 & 10,8 & 954 & 8,6 & 4,9 & 9 \\
\hline 4. Caraça & 10 & 0,5 & 68 & 0,6 & 6,8 & - \\
\hline 5. Córrego Seco & 21 & 1,1 & 158 & 1,4 & 7,5 & - \\
\hline 6. Congonhas & 94 & 5,3 & 536 & 4,8 & 5,7 & 5 \\
\hline 7. Itatiaia & 99 & 5,6 & 744 & 6,7 & 7,5 & 10 \\
\hline 8. Itaubira & 105 & 5,9 & 909 & 8,2 & 8,6 & 6 \\
\hline 9. Ouro Branco & 69 & 3,9 & 427 & 3,8 & 6,1 & 6 \\
\hline 10. Ouro Bueno & 44 & 2,4 & 218 & 1,9 & 4,9 & - \\
\hline 11. Ouro Fino & 104 & 5,9 & 817 & 7,4 & 7,8 & - \\
\hline 12. Ouro Podre & 63 & 3,5 & 583 & 5,3 & 9,2 & - \\
\hline 13. Ouro Preto & 208 & 11,8 & 874 & 7,9 & 4,2 & 88 \\
\hline 14. Padre Faria & 148 & 8,3 & 977 & 8,8 & 6,6 & 57 \\
\hline 15.São Bartolomeu & $174 \star$ & 9,8 & $1.384 \star \star$ & 12,5 & 7,9 & 13 \\
\hline \multirow[t]{2}{*}{$\begin{array}{l}\text { 16. Santo Antônio do } \\
\text { Campo }\end{array}$} & 125 & 7 & 692 & 6,2 & 5,5 & 2 \\
\hline & - & - & $265 \star \star \star$ & 2,4 & - & \\
\hline TOTAL & 1.761 & 100 & 10.991 & 100 & 6,2 & 267 \\
\hline
\end{tabular}

Fonte: APM, CMOP 11.

* O quantitativo de senhores em São Bartolomeu desconsiderou os residentes no lugar chamado Capanema, cujos nomes não foram revelados.

$\star \star \mathrm{O}$ total de escravos declarados em São Bartolomeu incluiu 140 cativos pertencentes aos moradores do lugar chamado Capanema, mas não mencionou os nomes de tais senhores e tampouco discriminou a distribuição dos escravos pelos plantéis.

$\star \star \star$ Escravos pertencentes aos sacerdotes residentes no Termo de Vila Rica. Os nomes dos religiosos e o tamanho dos plantéis individuais não foram revelados.

Novamente, a média geral de escravos por senhor não refletiu a situação real, desigualmente distribuída entre uma maioria de pequenos e uma mi- 
noria de médios e grandes proprietários. O Gráfico 4 explicitou esse contexto, ao demonstrar que uma fatia considerável da classe senhorial, formada por 347 senhores, quase um quinto do total, declarou posse de um único escravo $(19,6 \%)$. Outros 816 proprietários arrolaram escravaria de duas a cinco pessoas (46,3\%). Somadas, essas faixas representaram dois terços (66\%) dos senhores. Coletivos entre seis e dez escravos também atingiram montante significativo, com 330 registros, correspondentes a 18,7\%. Propriedades acima de dez escravos representaram, portanto, apenas quinze por cento do total.

\section{Gráfico 4 - Número de senhores por número de escravos no Termo de Vila Rica, quintos de 1721}

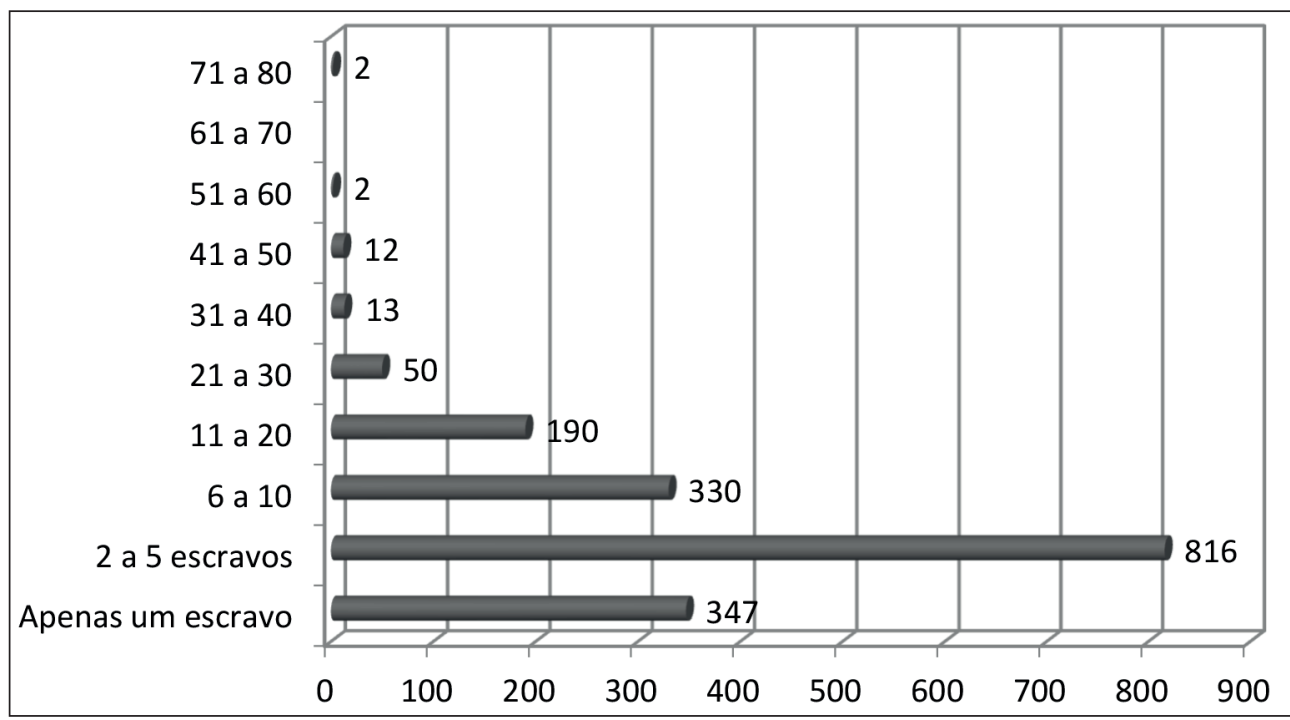

Fonte: APM, CMOP 11

No topo, a estratificação atingiu o máximo. Apenas dezesseis senhores ostentaram escravarias a superar quarenta pessoas, conformando a elite senhorial deVila Rica (0,9\%). E, no interior dessa elite, Henrique Lopes ocupou a posição mais elevada. No lançamento de 1721, o capitão-mor anotou o maior pagamento do Termo deVila Rica, no valor de 150 oitavas de ouro, referente à posse de oitenta escravos. Próximo ao principal pagador, com escravaria superior a setenta indivíduos, houve só o senhor Bento Gomes da Silva, no arraial de Ouro Podre, proprietário de setenta e nove escravos, pelos quais foi onerado em 148 oitavas de ouro e oitenta réis. Grandes proprietários, como João da Costa Brito (ou Brabo) e o capitão Antônio Ramos dos Reis, declararam escravarias inferiores, abaixo de sessenta indivíduos. Em vista de tais dados, pode-se afirmar que Henrique Lopes de Araújo transformou-se, então, pela primeira vez desde sua chegada às Minas, no indivíduo 
mais tributado de Vila Rica, destacando-se, simbolicamente, como seu principal minerador, conforme demonstra a Tabela 14. Coincidência ou não, o capitão-mor tornou-se nesse momento o provedor da residência oficial de dom Lourenço de Almeida, governador da recém-criada capitania de Minas Gerais.

\section{Tabela 14 - Relação dos maiores proprietários de escravos do Termo de Vila Rica, quintos de 1721}

\begin{tabular}{l|l|c}
\hline \multicolumn{1}{c|}{ Senhores } & \multicolumn{1}{c}{ Local } & No de escravos \\
\hline 1. Capitão-mor Henrique Lopes de Araújo & Antônio Dias & 80 \\
\hline 2. Bento Gomes da Silva & Ouro Podre & 79 \\
\hline 3. João da Costa Brito (Brabo) & Itaubira & 58 \\
\hline 4. Capitão Antônio Ramos dos Reis & Ouro Preto & 53 \\
\hline 5. João Alvarez da Rocha & Itaubira & 50 \\
\hline 6. Silvestre Coutinho & Itaubira & 48 \\
\hline 7. Francisco da Costa Ribeiro & Itaubira & 45 \\
\hline 8. Manoel de Mello e Horta & Ouro Podre & 45 \\
\hline 9. Tenente Coronel João Pinto da Silva & S. Bartolomeu & 44 \\
\hline 10. José Ferreira Cardoso & S. Bartolomeu & 43 \\
\hline 11. André Pires da Costa & Padre Faria & 43 \\
\hline 12. Pascoal Correia & S. Bartolomeu & 42 \\
\hline 13. João Gonçalves Batista & Ouro Podre & 42 \\
\hline 14. Antônio de Andrada e Góis & Antônio Dias & 41 \\
\hline 15. Manoel Dias da Costa & Itaubira & 40 \\
\hline 16. Francisco Leite de Brito & S. Bartolomeu & 40 \\
\hline 17. Capitão Francisco Leme da Silva & S. Bartolomeu & 44 \\
\hline
\end{tabular}

Fonte:APM, CMOP 11.

$\mathrm{Na}$ listagem do ano seguinte a situação pouco mudou. Houve crescimento do número geral de senhores e de escravos em relação a 1721. A freguesia de Antônio Dias manteve a primazia econômica. Considerando o arraial sede e ainda os distritos de Córrego Seco, Ouro Bueno, Ouro Fino, Padre Faria e Rio das Pedras, concentraram-se ali 634 senhores (33,4\%), 4.141 escravos $(35,2 \%)$ e 170 estabelecimentos comerciais (48,8\%), percentuais semelhantes aos do ano anterior, como se vê na Tabela 15 . O mais impres- 
sionante desenvolvimento se deu no arraial de Padre Faria, que conheceu aumento de 29\% em sua classe senhorial (de 148 para 192 proprietários) e de $26 \%$ no número de escravos (de 977 para 1.237 cativos), mesmo percentual de crescimento dos pontos comerciais (de 57 para 72 venda/lojas).

Outra vez a média geral de escravos mostrou-se enganosa. Na verdade, a maioria das entradas sequer alcançou cinco cativos por senhor. No Gráfico 5 observa-se que proprietários de escravo único e de escravarias entre dois e cinco cativos representaram dois terços do total (1.257 senhores, ou 66\%). As faixas intermediárias entre seis e vinte escravos também foram importantes, somando 558 registros, correspondentes a 29,3\%. Por fim, os portadores de coletivos acima de quarenta indivíduos constituíram a distinta elite da classe senhorial, formada por apenas dezessete grandes proprietários.

Tabela 15 - Número de pagantes, número de escravos, número médio de escravos por pagante e número de vendas por arraial no Termo de Vila Rica, quintos de 1722

\begin{tabular}{l|r|r|r|r|r|r}
\hline Arraial & Senhores & \% & Escravos & $\%$ & $\begin{array}{c}\text { Média de } \\
\text { escravos } \\
\text { por senhor }\end{array}$ & $\begin{array}{c}\text { Vendas/ } \\
\text { lojas }\end{array}$ \\
\hline 1. Antônio Dias & 230 & 12,1 & $1.095^{\star}$ & 9,2 & $4,7 \star \star$ & 98 \\
\hline 2. Bocaina & 97 & 5,3 & $457 \star$ & 3,9 & $4,4 \star \star$ & 12 \\
\hline 3. Cabeceiras S. Bárbara & 28 & 1,4 & 135 & 1,1 & 4,8 & 2 \\
\hline 4. Cachoeira do Campo & 188 & 9,9 & $1.038^{\star}$ & 8,7 & $5,3 \star \star$ & 6 \\
\hline 5. Congonhas & 34 & 1,7 & $231 \star$ & 1,8 & $6,7 \star \star$ & 3 \\
\hline 6. Congonhas [Nova das] & 83 & 4,3 & $440 \star$ & 3,6 & $5,0 \star \star$ & 4 \\
\hline 7. Córrego Seco & 16 & 0,8 & 150 & 1,2 & 9,3 & - \\
\hline 8. Itatiaia & 127 & 6,7 & $831 \star$ & 6,9 & $6,3 \star \star$ & 12 \\
\hline 9. Itaubira & 97 & 5,1 & $921 \star$ & 7,7 & $9,4 \star \star$ & 6 \\
\hline 10. Ouro Branco & 66 & 3,4 & $437 \star$ & 3,6 & $6,5 \star \star$ & 5 \\
\hline 11. Ouro Bueno & 33 & 1,7 & 187 & 1,5 & 5,6 & - \\
\hline 12. Ouro Fino & 93 & 4,9 & 810 & 6,8 & 8,7 & - \\
\hline 13. Ouro Preto & 225 & 11,8 & $1.011 \star$ & 8,5 & $4,3 \star \star$ & 106 \\
\hline 14. Padre Faria & 192 & 10,1 & 1.237 & 10,4 & 6,4 & 72 \\
\hline 15. Rio das Pedras & 70 & 3,6 & $662 \star$ & 5,6 & $9,4 \star \star$ & - \\
\hline 16. S. Antônio do Campo & 125 & 6,6 & 800 & 6,7 & 6,4 & 4 \\
\hline & & & & & & $($ continua \\
\hline
\end{tabular}


Tabela 15 - Número de pagantes, número de escravos, número médio de escravos por pagante e número de vendas por arraial no Termo de Vila Rica, quintos de 1722

\begin{tabular}{l|c|c|c|c|c|c}
\hline Arraial & Senhores & $\mathbf{\%}$ & Escravos & $\mathbf{\%}$ & $\begin{array}{c}\text { Média de } \\
\text { escravos } \\
\text { por senhor }\end{array}$ & $\begin{array}{c}\text { Vendas/ } \\
\text { lojas }\end{array}$ \\
\hline 17. São Bartolomeu & 189 & 9,9 & $1.295 \star$ & 10,9 & $6,8 \star \star$ & 18 \\
\hline 18. & 11 & 0,5 & 85 & 0,7 & & \\
\hline TOTAL & $\mathbf{1 . 9 0 4}$ & $\mathbf{1 0 0}$ & $\mathbf{1 1 . 8 2 2}$ & $\mathbf{1 0 0}$ & $\mathbf{6 , 0 \star \star}$ & $\mathbf{3 4 8}$ \\
\hline
\end{tabular}

Fonte: APM, CMOP 11.

* Contabilizados os escravos pertencentes a padres não identificados: em Antônio Dias (65), Bocaina (28), Cachoeira (33), Congonhas (4), Congonhas [Nova das] (20), Itatiaia (27), Itaubira (6), Ouro Branco (4), Ouro Preto (23), Rio das Pedras (6), São Bartolomeu (9).

$\star \star$ Foram desconsiderados os escravos pertencentes a religiosos não identificados.

\section{Gráfico 5 - Número de pagamentos por número de escravos no Termo de Vila Rica, quintos de 1722}

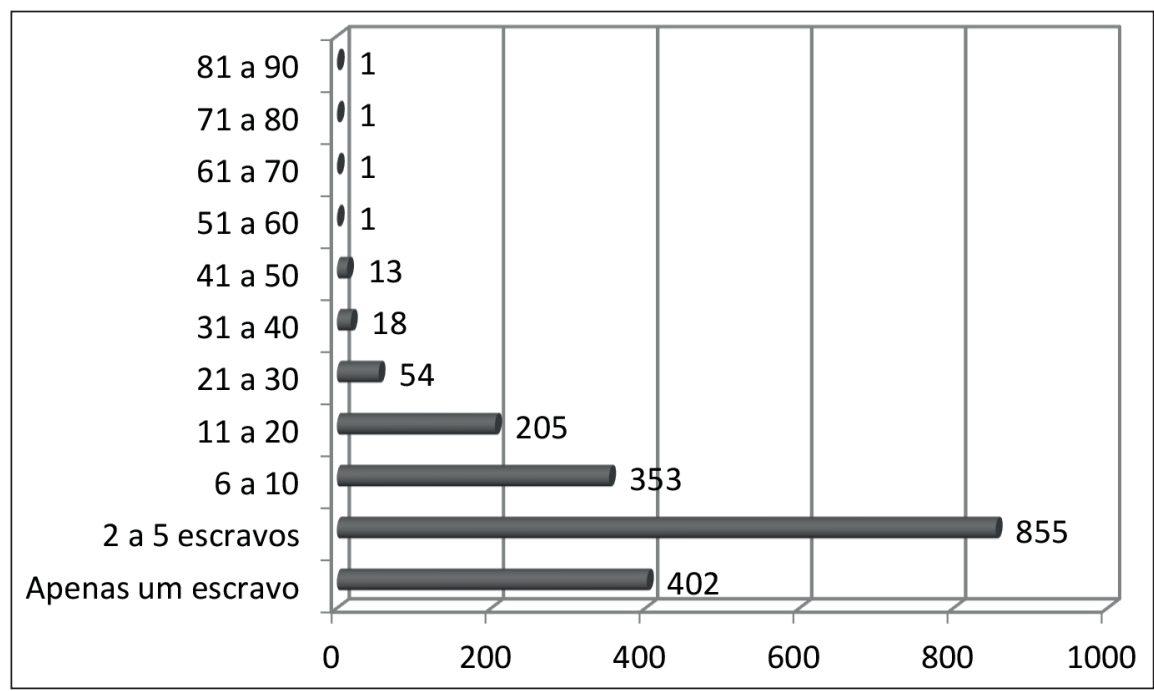

Fonte: APM, CMOP 11.

Em 1722, Henrique Lopes perdeu a condição de maior débito individual, sendo ultrapassado por outras entradas de vulto. O capitão-mor quitou aproximadamente 130 oitavas e meia de ouro por rol de setenta escravos. Em comparação com o ano anterior, suprimiram-se dez cativos, abatimento que significou economia de vinte oitavas de ouro no montante da dívida. Esse abrupto decréscimo faz pensar em sonegação. Mesmo assim, Henrique Lopes anotou o terceiro maior débito individual do Termo deVila Rica.Acima dele existiram 
apenas João da Costa Brito (ou Brabo), no arraial de Itaubira, com setenta e um escravos, e o já citado Bento Gomes da Silva, agora pagador no Rio das Pedras, por sua escravaria de oitenta e três cativos, como discrimina a Tabela 16.

Tabela 16 - Lista dos maiores proprietários de escravos do Termo de Vila Rica, quintos de 1722

\begin{tabular}{l|l|c}
\hline \multicolumn{1}{c|}{ Nome } & \multicolumn{1}{c}{ Local } & N. de escravos \\
\hline 1. Bento Gomes da Silva & Rio das Pedras & 83 \\
\hline 2. João da Costa Brito (Brabo) & Itaubira & 71 \\
\hline 3. Capitão-mor Henrique Lopes de Araújo & Antônio Dias & 70 \\
\hline 4. João Gonçalves Batista & Rio das Pedras & 55 \\
\hline 5. Capitão Antônio Ramos dos Reis & Ouro Preto & 50 \\
\hline 6. Francisco da Costa Ribeiro & Itaubira & 50 \\
\hline 7. Capitão Caetano Alvares de [Araújo] & C. do Campo & 46 \\
\hline 8. Capitão Domingos de Abreu Lisboa & Ouro Preto & 45 \\
\hline 9. Antônio de Andrada e Góis & Antônio Dias & 45 \\
\hline 10. João de Mello e Horta & Rio das Pedras & 44 \\
\hline 11. Pascoal Correia e Francisco Rodrigues & S. Bartolomeu & 43 \\
\hline 12. Silvestre Coutinho & Itaubira & 42 \\
\hline 13. Manoel Dias da Costa & Itaubira & 42 \\
\hline 14. André Pires da Costa & Padre Faria & 41 \\
\hline 15. Alferes Domingos Moreira Fernandes & Ouro Branco & 41 \\
\hline 16. Capitão Francisco Leite de Brito & S. Bartolomeu & 41 \\
\hline 17. João Rodrigues da Silva & S. Bartolomeu & 41 \\
\hline For APM CMOP 1. &
\end{tabular}

Fonte: APM, CMOP 11.

A lista dos maiores proprietários mudou pouco de um ano para outro. Em 1721, entre dezessete senhores principais, seis tinham suas propriedades situadas em áreas mineradoras da freguesia de Antônio Dias, incluindo o arraial sede e os distritos de Ouro Podre e Padre Faria. Dez advinham de áreas rurais, de feição agrícola: cinco no arraial de Itaubira e outros cinco em São Bartolomeu. Apenas um residia no arraial de Ouro Preto. Essa relação reforça a perspectiva de que a freguesia de Antônio Dias concentrasse o conjunto mais enriquecido de mineradores, ao passo que uma parcela cada vez maior dessa elite senhorial se espalhava por áreas rurais próximas à zona 
mineradora. Nesses arraiais, especialmente em São Bartolomeu, a mineração combinou-se à atividade agropastoril, absorvendo grande contingente de mão de obra cativa. Dado revelador consistiu na tímida participação do arraial de Ouro Preto entre as maiores escravarias. Comparados às propriedades vizinhas em Antônio Dias, os empreendimentos mineradores apresentaram no Pilar menor envergadura. A desvantagem parece ter sido compensada, por outro lado, pela pujança de seus estabelecimentos comerciais. Em 1721 e 1722, o distrito de Ouro Preto apresentou o mais robusto conjunto de lojas e vendas do Termo de Vila Rica. Talvez por isso, já nos quintos de 1715, o maior débito individual registrado no Pilar tenha sido anotado por um comerciante, JoãoVeloso de Carvalho, dono de uma loja de fazenda.Já em 1722, a distribuição dos principais senhorios manteve formato semelhante. $\mathrm{O}$ rol de grandes proprietários teve troca de apenas três nomes, além de oscilações numéricas nas listas. O capitão Domingos de Abreu Lisboa juntou-se ao capitão Antônio Ramos dos Reis, elevando a participação do arraial de Ouro Preto entre os principais pagadores dos quintos. Notem-se também as inclusões do capitão Caetano Alvares de Araújo, em Cachoeira do Campo, e do alferes Domingos Moreira Fernandes, em Ouro Branco. Manteve-se inalterado o quadro de prevalência de mineradores situados na freguesia de Antônio Dias, com seis representantes (incluindo-se os residentes em Rio das Pedras, Padre Faria e no próprio arraial de Antônio Dias).

A concentração de mineradores abastados na freguesia de Antônio Dias será tendência mantida ao longo da década de 1720 e quiçá ulteriormente, tornando a se manifestar entre 1729 e 1731, conforme será demonstrado nas listas de pagamento do Real Donativo.

\section{As listas do Real Donativo}

As listas de pagamento do Real Donativo elaboradas pela câmara de Vila Rica estenderam-se por três anos, entre 1729 e 1731. Embora fosse, em tese, uma contribuição voluntária, que visava subsidiar as núpcias de suas altezas reais - os infantes D. José, Príncipe do Brasil, e dona Maria Bárbara de Bragança, que se casaram, respectivamente, com os infantes espanhóis Maria Ana Vitória e D. Fernando, Príncipe das Astúrias - na prática o Real Donativo teve caráter tributário, ostensivamente exigido pelo rei (Fonseca; Paiva, 2010). ${ }^{18}$ Deliberada em junta local realizada em outubro de 1727 , a

${ }^{18}$ RAPM, v. 30, 1979, p. 265-66. 
extraordinária soma de cento e vinte e cinco arrobas de ouro deveria ser cobrada pro rata por cada uma das câmaras, conforme o rol de escravos de cada uma, além de quotas impostas às lojas, vendas, aos oficiais mecânicos e até mesmo àqueles que, não tendo ocupação nem cabedal próprios, pagariam como se escravos fossem. Ao Termo deVila Rica coube o montante de vinte mil oitavas de ouro. ${ }^{19}$ Expediram-se advertências aos cobradores no sentido de que não descuidassem das contribuições devidas por viandantes e por pessoas que se ausentassem de seus distritos para fugir à cobrança. Nas diligências arrecadatórias, os provedores podiam valer-se, inclusive, de oficiais de justiça e de milícias. ${ }^{20}$

Os róis de moradores, discriminados por distrito ou freguesia, especificaram o nome dos pagantes, seus quantitativos de escravos e de vendas (ou casas comerciais como lojas e cortes de carne) e o exercício de oficios mecânicos. Também nessas listas, assim como sucedera com os quintos de 1721 e 1722, o número total de cativos não deve ser tomado ao pé da letra, pois foram contadas como escravas pessoas livres que se dedicavam a trabalho manual semelhante ou igual ao realizado por não livres.

Entre 1729 e 1731, fabricaram-se vinte listas nominativas, quatro delas elaboradas no primeiro ano e as demais nos anos consecutivos. Embora se saiba que, nesse intervalo, cada freguesia ou distrito formador do Termo de Vila Rica tenha sido taxado anualmente, uma vez por ano, não é possível distinguir o período ou anuidade ao qual se referiram certas listas. Além disso, em alguns distritos, como a sede da freguesia do Pilar do Ouro Preto, não sobreviveram listas correspondentes aos três anos. As planilhas dos anos 1730 e 1731, por exemplo, embaralharam-se, sendo provável que tenham sido cobradas simultaneamente. Por outro lado, as divisões e subdivisões das freguesias e dos distritos modificaram-se de uma lista para outra, tornando dificil saber quantas vezes os moradores de uma mesma localidade foram levados a rol. Por isso, optou-se por considerar o conjunto de listas, sem divisá-las por ano. Esse procedimento implicou que um mesmo contribuinte pudesse aparecer em até três listas distintas, condizentes às imposições anuais efetuadas no triênio.

Esse foi o caso do capitão-mor Henrique Lopes de Araújo, levado a rol em três listas dos moradores da Freguesia de Antônio Dias referentes aos anos de 1729,1730 e 1731. Na primeira, assumiu escravaria formada por cerca de

\footnotetext{
${ }^{19}$ APM, SC 06, fls. $153 \mathrm{v}$.

${ }^{20}$ APM, CMOP cx. 02, doc. 5, fls. 2 e 3.
} 
setenta indivíduos; na seguinte, anotou posse de sessenta e sete cativos; e, na última, pagou por propriedade de sessenta e nove escravos. ${ }^{21}$ Comparativamente, a grandiosidade desse coletivo impressiona. No cômputo geral das listas do Real Donativo, a grande maioria dos contribuintes, em 69,3\% das entradas, arrolou posse de no máximo cinco escravos; outros 15,8\% apresentaram entre seis e dez escravos; $10,4 \%$ dos pagadores possuíam entre onze e vinte cativos. As demais faixas por dezenas obtiveram índices inferiores a três por cento. Chama atenção a seletividade dos principais senhores. Conforme exposto no Gráfico 6, em universo de 2.962 entradas, correspondentes aos pagantes dotados de propriedade escravista, existiram apenas cinco registros acima de cinquenta escravos $(0,16 \%)$. Entre esses cinco, três consistiam em cotas pagas por Henrique Lopes de Araújo. O maior débito pertenceu a Hierônimo Ribeiro da Costa, na lista da freguesia de São Bartolomeu em 1729, com propriedade de oitenta e um escravos. Além desses registros, o capitão Antônio Ramos dos Reis anotou cinquenta e quatro escravos, em lista de 1730, na freguesia do Pilar do Ouro Preto.

Perceba-se, portanto, que apesar de não ter arrolado a maior escravaria de 1730 - nesse ano, teve a segunda colocação -, cumulativamente Henrique Lopes de Araújo foi, sem dúvida, o principal contribuinte individual no Termo de Vila Rica, onerado em três listas consecutivas, sendo que em duas delas, as de 1729 e 1731, apresentou as mais robustas propriedades escravistas.

\section{Gráfico 6 - Número de pagamentos por número de escravos no Termo de Vila Rica, Real Donativo (1729-1731)}

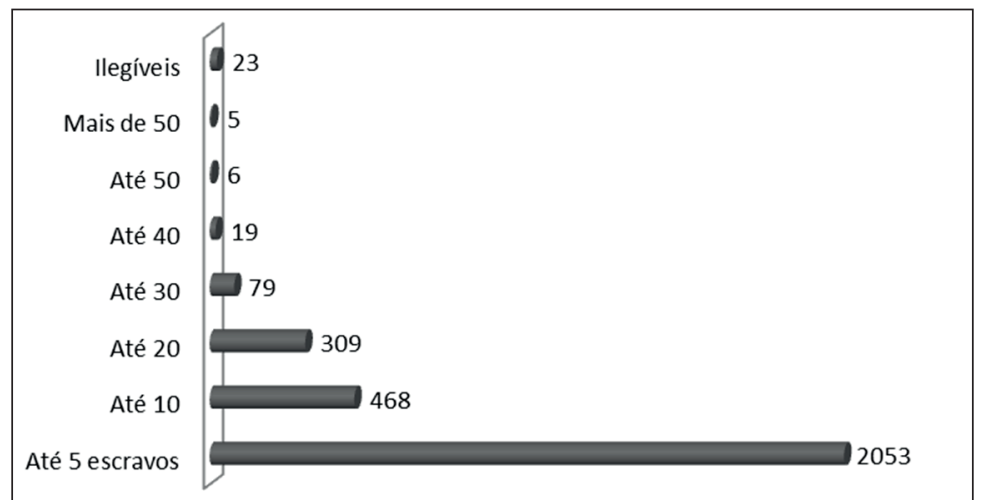

Fonte: APM, CMOP cx. 01, docs. 21, 22, 23, 24 e 25; cx. 02, docs. 05, 33, 34, 38, 40, 50, 51, 52, 54, 55, 56, 57 e 58 ; cx. 03, docs. 13 e 14.

\footnotetext{
${ }^{21}$ APM, CMOP cx. 02, doc. 34, fl. 4; e APM, CMOP cx. 02, doc. 54, fl. 3.
} 


\section{Tabela 17 - Lista dos principais senhores de escravos no Termo de Vila Rica, Real Donativo (1729-1731)}

\begin{tabular}{|c|c|c|}
\hline Nome & Local/Ano & N. de escravos \\
\hline 1. Hierônimo Ribeiro da Costa & São Bartolomeu (1730) & 80 \\
\hline $\begin{array}{l}\text { 2. Capitão-mor Henrique Lopes de } \\
\text { Araújo }\end{array}$ & Antônio Dias (1729) & 70 \\
\hline $\begin{array}{l}\text { 3. Capitão-mor Henrique Lopes de } \\
\text { Araújo }\end{array}$ & Antônio Dias (1730) & 67 \\
\hline $\begin{array}{l}\text { 4. Capitão-mor Henrique Lopes de } \\
\text { Araújo }\end{array}$ & Antônio Dias (1731) & 69 \\
\hline 5. Capitão Antônio Ramos dos Reis & Pilar do Ouro Preto (1730) & 54 \\
\hline 6. Licenciado João Gonçalves Batista & Ouro Fino/P. Faria/ Serra (1730) & 50 \\
\hline 7. Licenciado João Gonçalves Batista & $\begin{array}{l}\text { Ouro Fino/Padre Faria/ Serra } \\
(1730 / 31)\end{array}$ & 50 \\
\hline 8. Francisco Moreira & Jacutinga/Ouro Podre (1730) & 50 \\
\hline $\begin{array}{l}\text { 9. Capitão-mor Domingos da Rocha } \\
\text { Ferreira }\end{array}$ & $\begin{array}{l}\text { P. Faria/Taquaral/Bom Sucesso } \\
(1730)\end{array}$ & 50 \\
\hline 10. Capitão Francisco Leme de Brito & São Bartolomeu (1729) & 40 \\
\hline 11. Capitão Francisco Leme de Brito & São Bartolomeu (1729/30) & 35 \\
\hline 12. Capitão Francisco Leme de Brito & São Bartolomeu (1730) & 45 \\
\hline 13. Pascoal Correia de Aguiar & São Bartolomeu (1729) & 40 \\
\hline 14. Pascoal Correia de Aguiar & São Bartolomeu (1729/1730) & 43 \\
\hline 15. Pascoal Ferreira de Aguiar & São Bartolomeu (1730/31) & 38 \\
\hline $\begin{array}{l}\text { 16. Capitão Antônio Fernandes de } \\
\text { Araújo }\end{array}$ & Itaubira (1729) & 31 \\
\hline $\begin{array}{l}\text { 17. Capitão Antônio Fernandes de } \\
\text { Araújo }\end{array}$ & Itaubira $(1730)$ & 40 \\
\hline $\begin{array}{l}\text { 18. Capitão Antônio Fernandes de } \\
\text { Araújo }\end{array}$ & Itaubira (1731) & 39 \\
\hline 19. Manoel Moreira de Meireles & Itatiaia/Lavras Novas (1731) & 38 \\
\hline 20. Domingos de Abreu Lisboa & Jacutinga/Ouro Podre (1730) & 37 \\
\hline
\end{tabular}

Fonte: APM, CMOP cx. 01, docs. 21, 22, 23, 24 e 25; cx. 02, docs. 05, 33, 34, 38, 40, 50, 51, 52, 54, 55, 56, 57 e $58 ;$ cx. 03, docs. 13 e 14. 
Observe-se que, na lista constante na Tabela 17, constituída por onze indivíduos, há cinco proprietários sediados na freguesia de Antônio Dias, três em São Bartolomeu e apenas um nas freguesias do Pilar do Ouro Preto, Itaubira e Itatiaia/Lavras Novas, respectivamente. Tais dados permitem concluir que as áreas auríferas situadas em Antônio Dias abrigavam, àquela altura, os principais senhores do Termo deVila Rica. Por outro lado, no meio predominantemente rural, onde a mineração conjugava-se a atividades agropastoris, o arraial de São Bartolomeu destacou-se e suplantou os arraiais de Cachoeira do Campo (que sequer aparece na listagem), Itaubira e Itatiaia/Lavras Novas. Surpreendentemente, na sede da freguesia do Pilar, apenas o capitão Antônio Ramos dos Reis encontrou-se entre os principais detentores de mão de obra. Apesar de possuir densa ocupação demográfica, o Pilar não ostentou a mesma pujança mineradora do arraial vizinho.

\section{Conclusão}

Manejadas e cotejadas com cuidado e atenção às especificidades dos acervos, as listas fiscais de Vila Rica produzidas nos três lustros entre 1715 e 1731 permitem observar a complexidade econômica local e confirmam, até certo ponto, o prognóstico historiográfico que realça a importância de atividades agrícolas (mesmo nas proximidades de núcleos mineradores) e comerciais. Porém, também é verdade que existiram grandes senhores, proprietários de extensos plantéis escravistas, dedicados exclusivamente à extração aurífera. O caso de Henrique Lopes de Araújo é o maior exemplo disso.

Os dados demonstrados possibilitam rediscutir, ainda, a suposta timidez atribuída aos plantéis escravistas e à envergadura econômica dos empreendimentos mineradores. No período considerado,Vila Rica sempre deteve uma fração de sua classe senhorial com posses escravistas acima de quarenta cativos, que poderiam alcançar, nos maiores plantéis, mais de oitenta integrantes e talvez ultrapassassem a centena de membros, caso considerada a totalidade dessas propriedades escravistas. Essa fração, constituída por conjunto a oscilar entre quinze e vinte grandes proprietários, manteve sua primazia econômica no período. Embora por vezes conjugasse atividades extrativas àquelas voltadas ao abastecimento, essa elite também chegou a ser formada por agentes majoritariamente mineradores. As últimas listas com que trabalhamos, as do Real Donativo, demonstraram que, pelo menos, cinco dos grandes senhores atuavam em sítios eminentemente extrativos, como Antônio Dias, Padre Faria/ 
Serra, Bom Sucesso, Taquaral e Ouro Podre. Devido à presença e à importância dessa camada de grandes senhores, é preciso avaliar com cuidado as médias de escravizados por proprietário, pois elas podem dar impressão errônea ou enganosa da realidade. E vimos ainda que os níveis de concentração e desigualdade social foram, possivelmente, maiores em núcleos mineradores, se comparados aos mais populosos arraiais agrícolas e rurais.

Em síntese, os resultados obtidos para o Termo de Vila Rica entre 1715 e 1731 sugerem que a importância da mineração na economia local era colossal. Sem considerar a já aludida representatividade entre grandes senhores, a extração aurífera empregou, ali, a maior parte dos milhares de agentes econômicos proprietários de um até seis escravizados, preferencialmente residentes em arraiais de perfil minerador. Isso posto, apesar da diversificação econômica especialmente prolífica e não obstante a densa rede de pequenos, médios e grossos tratos mercantis que ligavam a região aurífera às demais praças do Brasil e do império português, a mineração subsistia como atividade econômica primordial no coração das Minas Gerais.

\section{Fontes manuscritas}

ANTT, Conde de Linhares, mç. 95/2. TESTAMENTO do Capitão-mor Henrique Lopes de Araújo. ANTT, Conde de Linhares, mç. 95/2.

APM, Casa dos Contos 1028.VILA Rica: Quintos, Capitão. 1718-1723.

APM, Casa dos Contos 1039.ANTÔNIO Dias: Quintos, Capitão. 1719-1723.

APM, Câmara Municipal de Ouro Preto cx. 01, docs. 21, 22, 23, 24 e 25;

APM, Câmara Municipal de Ouro Preto cx. 02, docs. 05, 33, 34, 38, 40, 50, $51,52,54,55,56,57$ e 58 ;

APM Câmara Municipal de Ouro Preto, cx. 03, docs. 13 e 14.

APM, Câmara Municipal de Ouro Preto 02, passim.

APM, Câmara Municipal de Ouro Preto 11, passim. 
APM, Seção Colonial 04, fls. 103-07.

APM, Seção Colonial 06, passim.

\section{Fontes publicadas}

RAPM, v. 30, 1979, p. 265-66.

\section{Referências}

BOTELHO, T. R. População e escravidão nas Minas Gerais, c. 1720. Anais do XII Encontro da Associação Brasileira de Estudos da População. Caxambu:Abep, 2002.

BOSCHI, C. C. Nem tudo que reluz vem do ouro. In: SZMRECSÁNYI,T. História econômica do período colonial. São Paulo: Hucitec, p. 57-66, 1996.

BOXER, C. R. A idade de ouro do Brasil: dores de crescimento de uma sociedade colonial. Rio de Janeiro: Nova Fronteira, 2000.

CARDOZO, M. S. The collection of the fifths in Brazil, 1695-1709. The Hispanic American Historical Review, v. 20, n. 3, p. 359-379, 1940.

CARRARA,A. Minas e Currais: produção rural e mercado interno de Minas Gerais. 1674-1807. Juiz de Fora: Editora UFJF, 2007.

COSTA, A. P. P. Armar escravos em Minas Colonial: potentados locais e suas práticas de reprodução social na primeira metade do século XVIII.Vila Rica, 1711-1750. Rio de Janeiro: UFRJ, 2010 (Tese de Doutorado em História Social da UFRJ).

COSTA, A. Sistemas fiscais no Império: o caso do ouro do Brasil, 1725-1777. Lisboa: ULisboa, 2013 (Tese de Doutorado em História Econômica e Social da ULisboa).

FARIA, S. C. Os "homens do ouro": perfil, atuação e redes dos Cobradores dos Quintos Reais em Mariana Setecentista. Rio de Janeiro: UFRJ, 2010 (Dissertação de Mestrado em História da UFRJ). 
FARIA, S. C.A "matéria dos quintos" e "os homens do ouro": a dinâmica da arrecadação dos quintos reais na capitania de Minas Gerais e as atribuições, atuação, perfil e relações dos cobradores dos quintos (c. 1700-c. 1780). Rio de Janeiro: UFRJ, 2015 (Tese de Doutorado em História da UFRJ).

FARIA, S. C. Para se tratar da matéria dos quintos: a dinâmica da arrecadação dos quintos reais em Minas Gerais (c. 1701-c. 1780). Nuevo Mundo Mundos Nuevos, 2013. Disponível em: < https://journals.openedition.org/nuevomundo/65822>. Acesso em: 14 mar. 2021.

FONSECA, C. D. Arraiais e Vilas D’El Rei: espaço e poder nas Minas setecentistas. Belo Horizonte: Editora UFMG, 2011.

FONSECA, M B.; PAIVA, E. F. Identidade étnica africana: escravidão e liberdade em Minas Gerais, século XVIII. Cesumar, v. 12, n. 1, 2010.

FURTADO, C. Formação econômica do Brasil. São Paulo: Companhia Editora Nacional, 2005.

FURTADO, J. Homens de Negócio: a interiorização da metrópole e do comércio nas Minas setecentistas. São Paulo: Hucitec, 2006.

GASPAR,T. de S. Tapanhuacanga em ruínas: história do PalácioVelho de Ouro Preto (c. 1660-1825). São Paulo: USP, 2016 (Tese de Doutorado em História Social da USP).

HOLANDA, S. B. de. Minas e metais preciosos. In: HOLANDA, S. B. de. História geral da civilização brasileira: a época colonial (volume 2). Rio de Janeiro: Bertrand Brasil, 2003.

LAMAS, F. G. Para além do ouro das Gerais: outros aspectos da economia mineira no setecentos. Heera. Revista de História Econômica E Economia Regional Aplicada, v. 3, n. 4, 2008, p. 37-54.

LIBBY, D. C. As populações escravas das Minas setecentistas: um balanço preliminar In: RESENDE, M. E. L. de;VILLALTA, L. C. (Org.) História de Minas Gerais: a província de Minas. Belo Horizonte:Autêntica; Companhia do Tempo, p. 407-438, 2007. 
MATA, K. P. da Representação social e riqueza nas Minas do Ouro: perfil dos proprietários de escravos na primeira metade do setecentos. Anais do XV Encontro da Associação Brasileira de Estudos da População. 2006, Caxambu. Caxambu: Abep, 2006.

MATHIAS, C. L. K. As múltiplas faces da escravidão: o espaço econômico do ouro e sua elite pluriocupacional na formação da sociedade mineira setecentista (c. 1711-c. 1756). Rio de Janeiro: Mauad X; FAPERJ, 2012.

VASCONCELLOS, D. P. R. de. Minas e quintos do ouro, Revista do Arquivo Público Mineiro, v. 6, n. 2, p. 855-965, 1901.

VASCONCELOS, S. de. Como nasceu Ouro Preto: sua formação cadastral desde 1712. Revista do IPHAN, n. 12, p. 171-232, 1955.

VASCONCELOS, S. de. Vila Rica: formação e desenvolvimento - residências. Rio de Janeiro: Ministério da Educação e Cultura; Instituto Nacional do Livro, 1956. 